\title{
Organizacja i przebieg \\ Narodowego Plebiscytu Pokoju \\ w województwie opolskim**
}

\section{ADRIANA DAWID}

Uniwersytet Opolski

(iD) https://orcid.org/0000-0002-5098-5974

DOI: https://doi.org/10.26774/rzz.277

$02 / 2018$

\section{ROCZNIK}

\section{ZIEM}

\section{ZACHODNICH}

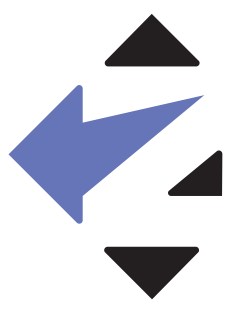

Publikacja dostępna na licencji Creative Commons Uznanie autorstwa - Na tych samych warunkach 4.0 Międzynarodowe. Pewne prawa zastrzeżone na rzecz autorów. Zezwala się na wykorzystanie publikacji zgodnie z licencją - pod warunkiem zachowania niniejszej informacji licencyjnej oraz wskazania Ośrodka „Pamięć i Przyszłość” jako właściciela praw do tekstu. 


\section{Wprowadzenie. Główne inicjatywy Ruchu Obrońców Pokoju (1948-1951)}

W napiętej atmosferze politycznej, gdy wkrótce po zakończeniu II wojny światowej narastało zagrożenie wybuchem kolejnego konfliktu zbrojnego, aktywował się międzynarodowy ruch obrońców pokoju. Inspirowany przez skrajną lewicę, ruch ten był elementem ówczesnej kampanii ideologicznej i politycznej realizowanej przez ZSRR, jej sojuszników oraz międzynarodowe struktury partii komunistycznej (Kominform). Działalność obrońców pokoju znajdowała żywy oddźwięk społeczny - powszechnie obawiano się skutków zarysowującego się coraz wyraźniej dwubiegunowego podziału świata oraz ewentualnego użycia nowych rodzajów broni, głównie atomowej. Między 25 a 28 sierpnia 1948 r. odbył się we Wrocławiu Światowy Kongres Intelektualistów w Obronie Pokoju, pierwsze ważne spotkanie organizacyjne pacyfistów. Wkrótce po tym, w kwietniu 1949 r., równolegle w Paryżu i Pradze odbył się z udziałem 2 tys. delegatów z 72 krajów I Światowy Kongres Obrońców Pokoju, podczas którego powstał Stały Komitet Światowego Kongresu Obrońców Pokoju na czele ze związanym z komunistyczną partią francuską prof. Frédérikiem Joliot-Curie. Polska była gospodarzem kolejnego Światowego Kongresu, który obradował 16-22 listopada 1950 r. Ponad 2 tys. delegatów z 81 krajów potępiło wówczas amerykańską interwencję w Korei, remilitaryzację Niemiec Zachodnich i Japonii oraz wyścig zbrojeń. W trakcie warszawskiego kongresu powołano do życia Światową Radę Pokoju, która miała odtąd kierować ruchem obrońców pokoju (przejęła obowiązki Stałego Komitetu Światowego Kongresu Obrońców Pokoju). Jej przewodniczącym został wymieniony już wyżej Joliot-Curie. Środowisko obrońców pokoju stało się istotnym elementem walki politycznej i ideologicznej - było narzędziem oddziaływania bloku radzieckiego na sytuację państw zachodnich i rządy państw należących do NATO. Ruch zyskał szerokie, ponadnarodowe ramy, skupiał przedstawicieli różnych środowisk i ugrupowań politycznych, wielu Kościołów i wyznań, przez co miał istotny wpływ na kształtowanie świadomości opinii publicznej. Zależny politycznie i finansowo od moskiewskiego kierownictwa, stał się ważnym orężem tworzonego wówczas „frontu antyimperialistycznego" ${ }^{1}$.

Ruch Obrońców Pokoju, oprócz organizowania krajowych i międzynarodowych kongresów, zebrań i konferencji urządzał również liczne masówki i manifestacje. Ważną formą jego aktywności były inicjatywy o zasięgu międzynarodowym. We wczesnym okresie działalności ruchu przeprowadzono np. dwie akcje zbierania podpisów pod apelami pokojowymi, które swym zasięgiem objąć miały setki milionów osób w dziesiątkach krajów. Pierwsza z takich akcji wiązała się z Apelem w sprawie zakazu stosowania broni atomowej, który w marcu 1950 r. ogłosił Stały Komitet podczas swych obrad w Sztokholmie. Ostatecznie apel na całym świecie podpisało ok. 500 mln osób. W niespełna rok później, w marcu 1951 r., obradująca w Berlinie Światowa Rada Pokoju ogłosiła apel o zawarcie Paktu Pokoju między mocarstwami światowymi. Kolejną podobną inicjatywę podjęto w 1955 r., gdy ogłoszono tzw. Apel wiedeński

* Tłumaczenie niniejszego artykułu na język angielski znajduje się w niniejszym numerze „Rocznika Ziem Zachodnich", s. 280-317. 
przeciw przygotowaniom do wojny jądrowej (podpisy pod nim złożyło ok. $700 \mathrm{mln}$ ludzi). Następne analogiczne apele pojawiły się dopiero w latach 70. XX w. ${ }^{2}$

W Polsce struktury organizacyjne Ruch Obrońców Pokoju zaczęły tworzyć się w 1949 r. W marcu tego roku powstał Polski Komitet Obrońców Pokoju (PKOP), na którego czele stanął marszałek Sejmu Ustawodawczego RP, prof. Jan Dembowski. Ruch stworzył rozbudowaną sieć Komitetów Obrońców Pokoju (KOP) od szczebla centralnego poprzez wojewódzkie, powiatowe i gminne, po gromadzkie czy zakładowe bądź osiedlowe. Od początku swej działalności PKOP włączał się w inicjatywy Ruch Obrońców Pokoju i występował z poparciem jego ideowego przesłania, aktywnie uczestniczył w pracach i decyzjach Stałego Komitetu, potem Światowej Rady Pokoju. Na początku lat 50. XX w. PKOP m.in. aktywnie wspierał kampanię potępiającą ingerencję USA w Korei i organizował pomoc dla „walczących o jedność kraju” obywateli tego kraju. W 1950 r. PKOP włączył się także w akcję zbierania podpisów pod Apelem sztokholmskim - oficjalnie inicjatywa ta w Polsce zyskała bezwzględne poparcie, ponieważ - jak ogłoszono - apel podpisali niemal wszyscy dorośli obywatele kraju. W niespełna rok później PKOP stanął przed zadaniem ponownego zmobilizowania obywateli Polski do podpisania nowego orędzia pokojowego, tzw. Apelu berlińskiego. Ta nowa inicjatywa pokojowa została ogłoszona przez Światową Radę Pokoju w lutym 1951 r. Był to de facto apel o zawarcie zaproponowanego przez Związek Radziecki w 1949 r. Paktu Pokoju między ZSRR, USA, Chinami, Wielką Brytanią i Francją. W myśl intencji Światowej Rady Pokoju do paktu mogłyby przystąpić później wszystkie państwa. Propozycja Apelu Światowej Rady Pokoju o zawarcie Paktu Pokoju między pięcioma wielkimi mocarstwami spotkała się z masowym, choć zorganizowanym i kontrolowanym przez partie komunistyczne poparciem. W myśl oficjalnego komunikatu Światowej Rady Pokoju na całym świecie pod apelem podpisało się $650 \mathrm{mln}$ ludzi. Wezwanie do zawarcia Paktu Pokoju zostało przekazane w marcu 1953 r. rządom pięciu wielkich mocarstw. Akcja zbierania podpisów nie przyniosła wymiernego efektu w postaci zawarcia Paktu Pokoju. Jej sukces miał wymiar głównie propagandowy - jasno przedstawiał ZSRR i jej sojuszników jako inicjatorów działań pokojowych, a państwa z konkurencyjnego bloku zachodniego jako imperialistów i zwolenników wojny. W Polsce PKOP na swym plenarnym posiedzeniu 31 marca 1951 r. uchwalił Manifest do Narodu Polskiego, zlecający składanie podpisów pod Apelem berlińskim. Nowa akcja zyskała nieco zmodyfikowaną oprawę - ogłoszono ją jako Narodowy Plebiscyt Pokoju, który miał trwać przez kilka dni od 17 maja. Podobnie jak w przypadku Apelu sztokholmskiego zyskano oficjalnie pełne poparcie społeczne, gromadząc pod apelem podpisy ok. $18 \mathrm{mln}$ dorosłych Polaków ${ }^{3}$.

Niniejszy tekst jest próbą charakterystyki przebiegu Narodowego Plebiscytu Pokoju w województwie opolskim. Wydarzenia te nie doczekały się dotąd szczegółowego opracowania i zostaną odtworzone na podstawie dokumentów archiwalnych i doniesień prasowych. Najbardziej wartościowe dla tego zagadnienia okazały się 
materiały komitetów terenowych PZPR z zasobów Archiwum Akt Nowych w Warszawie i Archiwum Państwowego w Opolu. Dokumenty Wojewódzkiego Komitetu Obrońców Pokoju (WKOP) w Opolu zachowały się niestety w formie szczątkowej, również mniej owocna od zakładanej okazała się kwerenda w Archiwum Instytutu Pamięci Narodowej i Archiwum Diecezjalnym w Opolu. Dopełnieniem bazy źródłowej są doniesienia prasowe publikowane m.in. w „Trybunie Robotniczej” i na łamach „Dziennika Zachodniego”.

\section{Przygotowania do Narodowego Plebiscytu Pokoju}

Pierwszą wyraźną reakcją w województwie opolskim na ogłoszony plebiscyt był zorganizowany w Opolu na początku kwietnia pięciotysięczny wiec, podczas którego uchwalono rezolucję popierającą manifest PKOP. Treść wezwania miała dowodzić, że opolanie akceptują pomysł plebiscytu i podzielają opinię władz o zagrożeniu dla pokoju ze strony Zachodu. W rezolucji stwierdzono m.in.: „Razem z całą ludzkością z milionami obrońców pokoju, którym przewodzi potężny Związek Radziecki, gotowi jesteśmy uczynić wszystko aby mordercy spod znaku dolara nie mogli zrealizować swych obłędnych planów zatopienia ludzkości w morzu krwi i łez"4.

Za organizację zapowiadanego na 17 maja plebiscytu odpowiedzialny był PKOP, który uruchomił do tej akcji swoje oddziały terenowe. W Opolu przewodniczącym WKOP był Leonard Sylwester, funkcję sekretarza pełnił Czesław Lewicki, siedziba wojewódzkiego zarządu KOP znajdowała się przy ul. Reymonta 16. Komitety Obrońców Pokoju pracowały nieregularnie, mobilizowane do różnych akcji - ostatnia przed plebiscytem dotyczyła zbiórki podarków dla dzieci koreańskich i zakończyła się na początku roku. W związku z tym struktury te wymagały pewnej reorganizacji, a w niektórych przypadkach aktywacji. 16 kwietnia w Opolu odbyło się rozszerzone plenum WKOP, podczas którego delegat PKOP z Warszawy referował uchwały berlińskiej sesji Światowej Rady Pokoju i zadania wynikające z niej dla ruchu. Do końca kwietnia podobne posiedzenia, podczas których omawiano plan pracy przed plebiscytem, odbyły się na szczeblach powiatowych, a na początku maja w gminnych komitetach pokojowych ${ }^{5}$. Odprawa dla przewodniczących powiatowych KOP-ów i pełnomocników WKOP została zaplanowana na 10 maja ${ }^{6}$. W trakcie kampanii przed Narodowym Plebiscytem Pokoju założono wiele nowych komitetów pokojowych. Powstawały one w zakładach pracy, spółdzielniach, państwowych gospodarstwach rolnych, gromadach i szkołach. W miastach tworzono je dla poszczególnych dzielnic, a nawet ulic czy bloków. Do 10 maja działało już 2790 KOP-ów, w tym 949 zakładowych i 562 szkolne. Wzrost organizacyjny komitetów nie przebiegał równomiernie, we wstępnej fazie przygotowań najsłabiej w powiatach

5 Archiwum Akt Nowych w Warszawie (dalej: AAN), Komitet Centralny (dalej: KC) PZPR w Warszawie, sygn. 237/VII-2659, Notatka Kom. Wyk. PKOP o stanie przygotowań do Narodowego Plebiscytu Pokoju na dzień 4 V 1951 r., k. 55 
brzeskim i prudnickim7? Późno przystąpiono też do zakładania komitetów miejskich w Opolu, Oleśnie i Prudniku . Dynamika wzrostu liczby komitetów była wysoka - podczas plebiscytu działało ich 3415, skupiały 19413 członków ${ }^{9}$. Do komitetów włączano z reguły osoby, które były już wcześniej znane ze swego zaangażowania społecznego, np. uczestniczyły w akcji zbierania podpisów pod Apelem sztokholmskim, czy pomocy dla Korei ${ }^{10}$. Zgodnie z odgórnymi wytycznymi skład komitetów nie mógł być przypadkowy - dbano o to, by znalazła się w nich reprezentacja kobiet, młodzieży, duchownych, osób bezpartyjnych i należących do PZPR. Ze względu na specyfikę regionu zwracano uwage, by w komitetach zasiadały osoby rodzimego pochodzenia. W województwie opolskim, poza nielicznymi wyjątkami, udało się stworzyć komitety, których skład tę różnorodność uwzględniał. W kwestii np. ludności rodzimej z niektórych powiatów raportowano, że jej reprezentanci stanowią 70\% składu komitetów ${ }^{11}$. Członkowie KOP-ów na czas akcji plebiscytowej byli zwalniani ze swoich obowiązków służbowych w ich zakładach pracy. W przypadku gdy któryś z komitetów okazywał się niewydolny, organizowano przy nim pomocnicze sekcje młodzieżowe, powstało ich 532 ${ }^{12}$. 30 kwietnia Wojewódzka Komisja Intelektualistów i Działaczy Katolickich, która działała przy współpracy z PKOP, zorganizowała w Opolu konferencję z udziałem delegatów z większości powiatów. W czasie obrad,

7 Opolszczyzna w pełni przygotowana do należytego przeprowadzenia Plebiscytu Pokoju, „Dziennik Zachodni”, z 10 V 1951 r.; 20674 agitatorów przeszkolono na Opolszczyźnie, „Trybuna Robotnicza”, z 9 V 1951 r.

8 Z oporami powstawały też komitety uliczne, powołano je do życia dopiero po wyraźnej interwencji pełnomocnika PKOP z Warszawy; AAN, KC PZPR w Warszawie, sygn. 237/VII-234, Sprawozdanie z wyjazdu służbowego do woj. opolskiego z 28 V 1951 r., k. 37.

9 Archiwum Państwowe w Opolu (dalej: APO), WKOP, sygn. 1, Sprawozdanie z działalności politycznej i organizacyjnej Woj. Komitetu Obrońców Pokoju w Opolu i terenowych Komitetów Obrońców Pokoju za 1951 r., nlb. (to sprawozdanie też w APO, Komitet Wojewódzki (dalej: KW) PZPR w Opolu, sygn. 256, k. 273-281). Por.: APO, KW PZPR w Opolu, sygn. 1733, Ocena kampanii Narodowego Plebiscytu Pokoju przez Egzekutywe KW PZPR Opole [25 V 1951 r.], nlb. O dynamice wzrostu liczby KOP-ów zob.: AAN, KC PZPR, sygn. 237/VII-1696, Wewnętrzny Biuletyn Informacyjny Referatu Sprawozdawczego KW PZPR w Opolu z 14 V 1951 r.; APO, KW PZPR w Opolu, sygn. 248, Informacja Wojewódzkiego Komitetu Obrońców Pokoju z przygotowań do Narodowego plebiscytu Pokoju z 3 V 1951 r., k. 30; ibidem, sygn. 248, k. 77, Informacja w sprawie przebiegu kampanii plebiscytowej z 18 V 1951 r.; 2790 Komitetów Obrońców Pokoju pracuje na terenie woj. opolskiego, "Trybuna Robotnicza”, z 13 V 1951 r: 20674 agitatorów... Jak szybkie było tempo zakładania komitetów, ilustruje przykład z powiatu grodkowskiego, gdzie przed plebiscytem było 26 komitetów, a do 10 maja zorganizowano ich 194. APO, Komitet Powiatowy (dalej: KP) PZPR w Grodkowie, sygn. 43/VI/6, Sprawozdanie opisowe Powiatowego Komitetu z organizacji i przebiegu Narodowego Plebiscytu Pokoju na terenie powiatu grodkowskiego [1951 r.], nlb. W Opolu liczba komitetów miejskich wzrosła w tym czasie z 128 do 170. APO, Komitet Miejski (dalej: KM) PZPR w Opolu, sygn. 50/ IV/3, Protokół z posiedzenia Egzekutywy KM PZPR w Opolu z 15 V 1951 r., k. 164-166.

10 Np. APO, KP PZPR w Raciborzu, sygn. 53/II/1, Sprawozdanie z przebiegu plebiscytu narodowego na terenie Raciborza, nlb.

11 AAN, KC PZPR w Warszawie, sygn. 237/VII-234, Sprawozdanie z wyjazdu służbowego do woj. opolskiego z 28 V 1951 r., k. 38. Całkowicie zdominowane przez autochtonów miały być komitety w Walcach, Biedrzychowicach, Gostomii, Kornicy, Głogówku i Białej Prudnickiej. Tysiqce mieszkańców Opolszczyzny biorq udział w przygotowaniach do Plebiscytu Pokoju, „Trybuna Robotnicza” z 15 V 1951 r. W powiecie namysłowskim kobiety stanowiły 60\% obsady komitetów; Cała Opolszczyzna dokumentuje swq wole walki o pokój i Plan 6-letni, „Trybuna Robotnicza”, z 12 V 1951 r. W myśl niektórych doniesień było to aż $90 \%$. Zob. np.: Tysiqce mieszkańców Opolszczyzny...

1211.313 młodzieżowych agitatorów na Opolszczyźnie wyruszyło $w$ teren aby głosić hasła pokoju, „Trybuna Robotnicza", z 14 V 1951 r.; Cała Opolszczyzna dokumentuje... 
którym przewodniczył ks. prof. Michał Banach, zebrani omówili udział w plebiscycie duchownych i działaczy świeckich oraz zaapelowali do wszystkich o aktywne włączenie się w przygotowania ${ }^{13}$.

Do kontrolowania przygotowań WKOP wyznaczyła pełnomocników na poszczególne powiaty. Całą akcję monitorowały powołane przy komitetach wojewódzkim i powiatowych sekcje sprawozdawczo-ewidencyjne. $\mathrm{Z}$ ramienia PKOP przebieg plebiscytu w województwie opolskim obserwowało trzech pełnomocników z Warsza$w^{14}$. Na szczeblu powiatowych KOP-ów powoływano pełnomocników na poszczególne gminy i łączników do kontaktu z organizacjami masowymi ${ }^{15}$.

Komitety terenowe powoływały tzw. agitatorów pokoju, którzy mieli docierać do wyborców, dostarczać im karty i tłumaczyć cel plebiscytu. Jak podkreślał I sekretarz KW PZPR w Opolu Roman Nowak, jeden agitator miał przypadać na 10-15 osób ${ }^{16}$. Do 10 maja wytypowano ich $34524^{17}$. Wojewódzki Komitet Obrońców Pokoju raportował, że do akcji plebiscytowej zaangażowano ostatecznie 46148 agitatorów, z tego $65 \%$ bezpartyjnych i miejscowego pochodzenia ${ }^{18}$.

Wszyscy aktywnie pracujący w kampanii mieli zostać objęci szkoleniem, podczas którego zapoznawano ich z założeniami ideowymi i celem plebiscytu oraz przygotowywano do publicznych wystąpień i rozmów z wyborcami. Najpierw 19 kwietnia odbyła się odprawa pełnomocników z komitetu wojewódzkiego, następnie ci przeszkolili prelegentów w komitetach powiatowych, a oni spotkali się z członkami komitetów gromadzkich, zakładowych i in. Do 10 maja zorganizowano 606 seminariów,

13 AAN, KC PZPR w Warszawie, sygn. 237/VII-2659, Biuletyn Informacyjny Komitetu Wykonawczego Polskiego Komitetu Obrońców Pokoju nr 1 z 4 V 1951 r., k. 99; Inteligencja i działacze katoliccy Opolszczyzny włączajq się do akcji Narodowego Plebiscytu Pokoju, „Dziennik Zachodni”, z 5 V 1951 r.

14 APO, KW PZPR w Opolu, sygn. 1733, Ocena kampanii Narodowego Plebiscytu Pokoju przez Egzekutywę KW PZPR Opole [25 V 1951 r.], nlb.; ibidem, sygn. 248, Informacja Wojewódzkiego Komitetu Obrońców Pokoju z przygotowań do Narodowego plebiscytu Pokoju z 3 V 1951 r., k. 30; Po zakończeniu Plebiscytu Pokoju na Opolszczyźnie, „Trybuna Robotnicza”, z 25 V 1951 r.

15 Np. APO, KP PZPR w Głubczycach, sygn. 42/II/1, Sprawozdanie Powiatowego Komitetu Obrońców Pokoju w Głubczycach [1951 r.], nlb.

16 APO, KW PZPR w Opolu, sygn. 248, Protokół nr 17/51 z posiedzenia Egzekutywy KW PZPR w Opolu z 4 V 1951 r., k. 9.

17 AAN, KC PZPR, sygn. 237/VII-1696, Wewnętrzny Biuletyn Informacyjny Referatu Sprawozdawczego KW PZPR w Opolu z 11 V 1951 r. Według raportu z pierwszego dnia plebiscytu było ich 36 513. APO, KW PZPR w Opolu, sygn. 248, Informacja w sprawie przebiegu kampanii plebiscytowej z 18 V 1951 r., k. 77; ibidem, sygn. 1733, Ocena kampanii Narodowego Plebiscytu Pokoju przez Egzekutywę KW PZPR Opole [25 V $1951 \mathrm{r}]$, nlb.

18 APO, KW PZPR w Opolu, sygn. 1733, Ocena kampanii Narodowego Plebiscytu Pokoju przez Egzekutywę KW PZPR Opole [25 V 1951 r.], nlb. Według raportu z pierwszego dnia plebiscytu było ich 55401 APO, KW PZPR w Opolu, sygn. 248, Informacja w sprawie przebiegu kampanii plebiscytowej z 18 V 1951 r., k. 77. Dane te wydają się jednak zawyżone i podobnie jak w przypadku liczby KOP-ów (patrz przypis wyżej) bardziej wiarygodne wydają się liczby podane w podsumowaniu akcji przez WKOP na posiedzenie Egzekutywy KW PZPR w Opolu 25 V 1951 r. W 1952 r. WKOP podawał, że do kampanii zaangażowano łącznie 45586 osób. APO, WKOP, sygn. 1, Sprawozdanie z działalności politycznej i organizacyjnej Woj. Komitetu Obrońców Pokoju w Opolu i terenowych Komitetów Obrońców Pokoju za 1951 r., nlb. 
w których uczestniczyło 19494 agitatorów ${ }^{19}$. Seminaria trwały do 13 maja. Według sprawozdań przedłożonych KW PZPR w Opolu wzięło w nich udział 27108 osób²0. Na znaczenie szkoleń zwracał uwagę I sekretarz KW PZPR w Opolu Roman Nowak, który podkreślał, że agitatorów należy właściwie przygotować „wobec spodziewanych pytań ze strony ludności a szczególnie miejscowej. Tym bardziej, że materiały w broszurze wydanej przez PKOP są dla terenu opolskiego niewystarczające" ${ }^{\prime 21}$. Szkolenia opierały się na treściach zawartych w broszurze PKOP 17 Maja Narodowy Plebiscyt Pokoju, która zawierała 10 pytań i odpowiedzi dotyczących akcji. Podczas spotkań rozdzielano materiały propagandowe, tj. treści przemówień, hasła, instrukcje, karty itp. ${ }^{22} \mathrm{Na}$ kilka dni przed terminem plebiscytu agitatorzy udawali się na wyznaczony im teren i spotykali się z uprawnionymi do głosowania. Przekazywali im karty pokoju oraz broszury, tłumaczyli cel i znaczenie plebiscytu, a także instruowali, gdzie i kiedy będzie można głosować23.

Oprócz typowania i szkolenia agitatorów KOP-y organizowały również spotkania z wyborcami w poszczególnych gromadach, zakładach itp., były odpowiedzialne także za przygotowanie spisów ludności ${ }^{24}$. Do komitetów trafiały też pisemne wypowiedzi mieszkańców, czasem z załączonym zdjęciem, z uzasadnieniem, dlaczego podpisują apel pokoju ${ }^{25}$.

19 AAN, KC PZPR, sygn. 237/VII-1696, Wewnętrzny Biuletyn Informacyjny Referatu Sprawozdawczego KW PZPR w Opolu z 11 V 1951 r. Zob. też ibidem, sygn. 237/VII-2659, Notatka Kom. Wyk. PKOP o stanie przygotowań do Narodowego Plebiscytu Pokoju na dzień 4 maja 1951 r., k. 56; APO, KW PZPR w Opolu, sygn. 248, Informacja Wojewódzkiego Komitetu Obrońców Pokoju z przygotowań do Narodowego plebiscytu Pokoju z 3 V 1951 r., k. 30; APO, WKOP, sygn. 1, Sprawozdanie z działalności politycznej i organizacyjnej Woj. Komitetu Obrońców Pokoju w Opolu i terenowych Komitetów Obrońców Pokoju za 1951 r., nlb.

20 APO, KW PZPR w Opolu, sygn. 1733, Ocena kampanii Narodowego Plebiscytu Pokoju przez Egzekutywę KW PZPR Opole [25 V 1951 r.], nlb.; ibidem, sygn. 248, k. 44, Protokół z posiedzenia Egzekutywy KW PZPR w Opolu z 11 V 1951 r.; AAN, KC PZPR w Warszawie, sygn. 237/VII-234, Sprawozdanie z wyjazdu służbowego do woj. opolskiego z 28 V 1951 r., k. 38. Według raportu WKOP z 1952 r. przeszkolono 26173 agitatorów. APO, WKOP, sygn. 1, Sprawozdanie z działalności politycznej i organizacyjnej Woj. Komitetu Obrońców Pokoju w Opolu i terenowych Komitetów Obrońców Pokoju za 1951 r., nlb.

21 APO, KW PZPR w Opolu, sygn. 248, Protokół z posiedzenia Egzekutywy KW PZPR w Opolu z 4 V 1951 r. k. 9.

22 Ibidem, k. 77, Informacja w sprawie przebiegu kampanii plebiscytowej z 18 V 1951 r.; APO, KP PZPR w Głubczycach, sygn. 42/II/1, Sprawozdanie Powiatowego Komitetu Obrońców Pokoju w Głubczycach [1951 r.], nlb.

23 APO, KW PZPR w Opolu, sygn. 1733, Ocena kampanii Narodowego Plebiscytu Pokoju przez Egzekutywę KW PZPR Opole [25 V 1951 r.], nlb.; 39 tys. aktywistów na Opolszczyźnie bierze czynny udział w przygotowaniach do Plebiscytu Pokoju, „Trybuna Robotnicza”, z 11 V 1951 r.

2420674 agitatorów...

25 APO, KP PZPR w Głubczycach, sygn. 42/II/1, Sprawozdanie Powiatowego Komitetu Obrońców Pokoju w Głubczycach [1951 r.], nlb. 


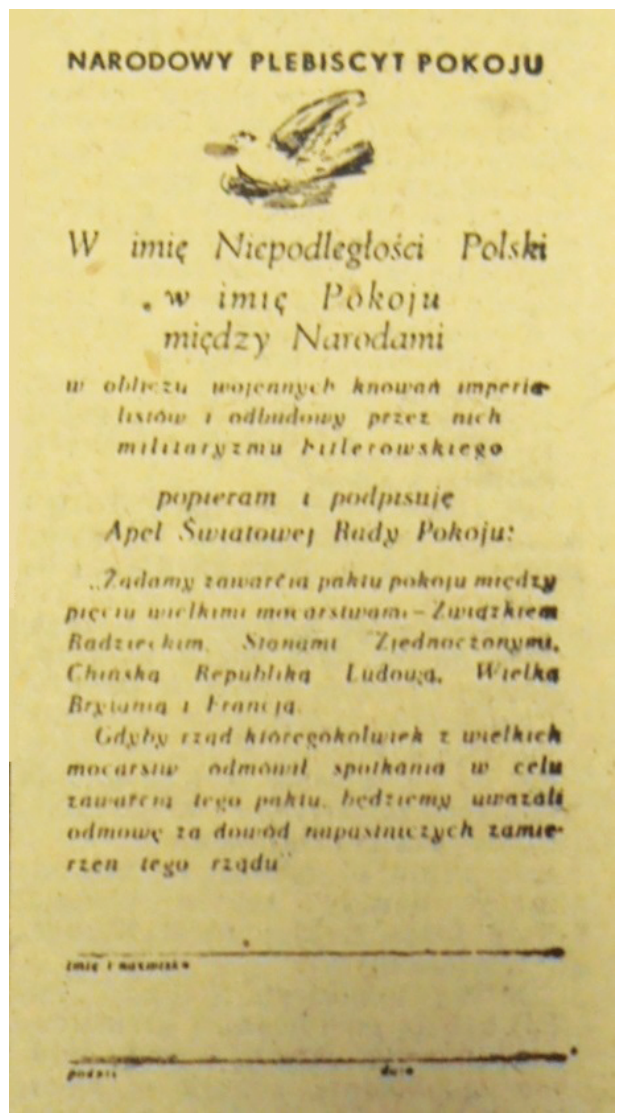

Il. 1. Reprodukcja karty, którą składano podczas Narodowego Plebiscytu Pokoju 17-22 V 1951 r. „Dziennik Zachodni”, z 17 V 1951 r.

Narodowy Plebiscyt Pokoju nie spełniał standardów typowego głosowania. Przede wszystkim karty otrzymywano wcześniej od agitatorów, którzy wpisywali na nich imię i nazwisko osoby, która miała ją złożyć. Uprawnieni do głosowania podpisywali karty, następnie osobiście, jawnie składali je w wyznaczonych do tego punktach między 17 a 22 maja. Mogli je oddać wszyscy, którzy ukończyli 15 lat. Karty były prostokątne, $\mathrm{z}$ emblematem gołąbka u góry.

Pod nim widniał wydrukowany na niebiesko tekst następującej treści:

W imię Niepodległości Polski w imię Pokoju między Narodami w obliczu wojennych knowań imperialistów i odbudowy przez nich militaryzmu hitlerowskiego popieram i podpisuję Apel Światowej Rady Pokoju „Żądamy zawarcia paktu pokoju między pięciu wielkimi mocarstwami - Związkiem Radzieckim, Stanami Zjednoczonymi, Chińską Republiką Ludową, Wielką Brytanią i Francją. Gdyby rząd któregokolwiek z wielkich mocarstw odmówił spotkania w celu zawarcia tego paktu będziemy uważali odmowę za dowód napastniczych zamierzeń tego rządu"26. 
U dołu wpisywano imię i nazwisko osoby, która kartę składała, a pod nim było miejsce na podpis i datę. Oprócz kart w języku polskim dla mieszkańców województwa opolskiego przygotowano też wersje $\mathrm{z}$ tekstem napisanym po niemiecku ${ }^{27}$.

Mimo oficjalnych zapewnień, że Narodowy Plebiscyt Pokoju jest inicjatywą realizowaną przez PKOP, jego przebieg był ściśle kontrolowany przez PZPR. W województwie opolskim sprawę głosowania omawiano po raz pierwszy na zebraniu Egzekutywy KW PZPR 20 kwietnia 1951 r. Jadwiga Ludwińska przedstawiła wówczas cel i termin plebiscytu. Ustalono wtedy, że członkowie partii wejdą w skład KOP-ów wszystkich szczebli i będą odpowiadać przed partią za właściwe przeprowadzenie głosowania ${ }^{28}$. Przed 17 maja kampanię omawiano jeszcze dwukrotnie na poszerzonych zebraniach KW z udziałem I sekretarzy KP PZPR, kierowników Wydziałów Propagandy KP PZPR i aktywistów WKOP oraz kierowników organizacji masowych. Do 10 maja przeprowadzono również poświęcone plebiscytowi 172 plena komitetów gminnych i miejskich PZPR oraz 1746 zebrań partyjnych (w zakładach pracy 396, w komitetach miejskich 443 i gromadzkich 548, w spółdzielniach produkcyjnych 147), w których uczestniczyły łącznie 28772 osoby ${ }^{29}$. Ta mobilizacja aktywu partyjnego została podjęta po to, by, jak zaznaczono, uniknąć niedociągnięć organizacyjnych, które wystąpiły podczas przygotowań do obchodów 1 Maja. Rolę partii w kampanii wyjaśniła Ludwińska na zebraniu Wydziału Organizacyjnego KW PZPR w Opolu:

Plebiscytem kierują wyłącznie KOP, które są w całości odpowiedzialne za przeprowadzenie Plebiscytu. Cała organizacja partyjna, wszystkie POP muszą być uruchomione w tej akcji. W skład KOP winien wchodzić również członek partii. Należy PKOP tak przegrupować żeby mogły być tym kierownikiem przeprowadzenia tej akcji. Tam gdzie nie ma przedstawicieli naszej partii w PKOP to należy tak zorganizować aby w każdym PKOP był nasz przedstawiciel [...]. Skład osobowy to jest tajemnica partyjna i państwowa, co pięć dni powinien mieć KW sprawozdanie z przebiegu akcji ${ }^{30}$.

Zapowiedzi te zostały zrealizowane - członkowie partii zdominowali skład i działalność komitetów pokojowych, które działały pod kontrolą i presją władz partyjnych ${ }^{31}$.

27 APO, KP PZPR w Brzegu, sygn. 41/VII/2, Protokół zdawczy kart plebiscytowych Powiatowego Komitetu Obrońców Pokoju z 22 V 1951 r., nlb.

28 APO, KW PZPR w Opolu, sygn. 247, Protokół nr 15/51 z posiedzenia Egzekutywy KW PZPR w Opolu z 20 IV 1951 r., k. 189

29 AAN, KC PZPR, sygn. 237/VII-1696, Wewnętrzny Biuletyn Informacyjny Referatu Sprawozdawczego KW PZPR w Opolu z 11 V 1951 r.; APO, KW PZPR w Opolu, sygn. 1733, Ocena kampanii Narodowego Plebiscytu Pokoju przez Egzekutywę KW PZPR Opole [25 V 1951 r.], nlb.

30 APO, KW PZPR w Opolu, sygn. 988, Protokół z odprawy Wydziału Organizacyjnego [kwiecień 1951 r.], k. 38.

31 Zob. np.: APO, KM PZPR w Opolu, sygn. 50/IV/3, Sprawozdanie z akcji przygotowawczej i przebiegu Ogólnopolskiego Plebiscytu Pokoju w Opolu [1951 r.], k. 73-77; APO, KP PZPR w Oleśnie, sygn. 49/IV/5, Sprawozdanie z przebiegu akcji plebiscytowej na terenie powiatu oleskiego, nlb.; AAN, KC PZPR w Warszawie, sygn. 237/VII-234, Sprawozdanie z wyjazdu służbowego do woj. opolskiego z 28 V 1951 r., k. 36, 38. 
Akcja ta była opatrzona dość szczegółową sprawozdawczością. Warto zaznaczyć, że nie stanowiła wyjątku, ponieważ podobnym zakresem opisów i raportów były wówczas objęte również inne działania PZPR. Dla porządku należy jednak zaznaczyć, że komitety powiatowe partii miały przekazywać do KW codzienne sprawozdania dotyczące udziału komitetów terenowych partii w akcji plebiscytowej ${ }^{32}$. Regularne raporty z kampanii Referat Sprawozdawczy KW PZPR w Opolu przekazywał do KC partii.

W kampanię plebiscytową zaangażować się miała również jak najszersza grupa organizacji masowych, reprezentanci różnych grup zawodowych i społecznych. W prace przygotowawcze włączyli się członkowie Związku Młodzieży Polskiej (ZMP), Zjednoczonego Stronnictwa Ludowego (ZSL), Stronnictwa Demokratycznego (SD) i Ośrodek Szkolenia Zawodowego. Związek Nauczycielstwa Polskiego (ZNP) oddelegował do akcji 596 nauczycieli. Swoich przedstawicieli do kampanii plebiscytowej skierowały także Związek Samopomocy Chłopskiej (ZSCh) i Liga Kobiet, choć ich udział w akcji był mniejszy od oczekiwanego. Członkowie tych organizacji urządzali spotkania, pogadanki i wykłady poświęcone plebiscytowi lub sami podejmowali obowiązki agitatorów. W województwie opolskim jako szczególnie aktywnych wskazywano członków SD oraz nauczycieli. Wyróżniali się także młodzi członkowie ZMP, w niektórych regionach stanowili ponad połowę agitatorów ${ }^{33}$.

\section{Działania propagandowe}

W omawianym okresie społeczeństwo polskie permanentnie było wciągane w kolejne akcje i kampanie, obchody i zbiórki. Narodowy Plebiscyt Pokoju zbiegł się w czasie z kilkoma tego typu inicjatywami, co spowodowało, że jego założenia prezentowano także przy innych okazjach. I tak np. zapowiedzi plebiscytu pojawiły się już podczas kampanii z okazji Święta Pracy. Hasła pokojowe zdominowały także przypadające na 3-15 maja Dni Oświaty, Książki i Prasy. Również uroczystości z okazji Święta Ludowego (13 maja) stały się pretekstem do popularyzowania plebiscytu i podejmowania rezolucji o masowym w nim udziale ${ }^{34}$.

W okresie poprzedzającym plebiscyt organizowano wiece i zbiórki, podczas których członkowie KOP-ów oraz agitatorzy przekonywali do udziału w nim. Część

32 Zob. np. APO, KP PZPR w Grodkowie, sygn. 43/VI/6, Ankieta Sprawozdawcza z przebiegu przygotowań do Plebiscytu Pokoju z 14 V 1951 r.

33 Odczyt o Plebiscycie Pokoju, „Trybuna Robotnicza”, z 11 V 1951 r.; Idea pokoju pogłębia się wśród ludności powiatu namysłowskiego, „Dziennik Zachodni”, z 11 V 1951 r.; Inteligencja pracująca w Prudniku włacza sie do służby dla pokoju, „Dziennik Zachodni”, z 14 V 1951 r.; 2790 Komitetów Obrońców Pokoju...; 20674 agitatorów...; Pozytywny stosunek opolskich rzemieślników do Frontu Narodowego i plebiscytu Pokoju, „Dziennik Zachodni", z 8 V 1951 r.; APO, KP PZPR w Grodkowie, sygn. 43/VI/6, Sprawozdanie opisowe Powiatowego Komitetu z organizacji i przebiegu Narodowego Plebiscytu Pokoju na terenie powiatu grodkowskiego [1951 r.], nlb.; APO, KW PZPR w Opolu, sygn. 248, Informacja Wojewódzkiego Komitetu Obrońców Pokoju z przygotowań do Narodowego plebiscytu Pokoju z 3 V 1951 r., k. 30.

34 Ibidem, sygn. 2066, Wydział Propagandy KW PZPR w Opolu do I Sekretarza KP PZPR w Koźlu z 26 IV 1951 r., k. 18-19; APO, KP PZPR w Oleśnie, sygn. 49/IV/5, Sprawozdanie z przebiegu akcji plebiscytowej na terenie powiatu oleskiego, b.p.; APO, KP PZPR w Głubczycach, sygn. 42/II/1, Sprawozdanie Powiatowego Komitetu Obrońców Pokoju w Głubczycach [1951 r.], nlb.; APO, KM PZPR w Opolu, sygn. 50/IV/3, Protokół z posiedzenia Egzekutywy KM PZPR w Opolu z 15 V 1951 r., k. 172-175; Obchody Święta Ludowego z udziałem wicepremiera Korzyckiego, „Dziennik Zachodni”, z 15 V 1951 r. 
z tych spotkań uzupełniały występy artystyczne, przygotowane np. przez zespoły świetlicowe. Przemówienia członków KOP-ów poprzedzały w tym okresie także imprezy sportowe. W niektórych zakładach pracy pogadanki o plebiscycie urządzano nawet podczas przerw śniadaniowych. Tego typu spotkania organizowane były nie tylko przez KOP-y, ale także organizacje masowe, zarówno w miastach, jak i małych wioskach. Na spotkaniach tych wypowiadali się również mieszkańcy regionu, którzy wyrażali swoje opinie na temat zagrożenia wojną i metod utrzymania pokoju. Głos oddawano inwalidom wojennym, a także dzieciom, głównie sierotom, oraz matkom, które apelowały o zachowanie pokoju w trosce o swoje potomstwo. Sięgano również do sprawdzonych w regionie autorytetów, jak np. Jana Wawrzynka, znanego w Opolskiem przedwojennego działacza polskiego, więźnia obozu koncentracyjnego. Wysłuchiwano wypowiedzi zarówno osób, które w czasie II wojny światowej przeżyły okupację niemiecką, jak i mężczyzn rodzimego pochodzenia, którzy służyli w Wehrmachcie. Część z tych wystąpień cytowano na łamach prasy, gdzie dość szeroko prezentowano przebieg przedplebiscytowych spotkań ${ }^{35}$. I tak np. pracownik jednego z PGR-ów deklarował: „My traktorzyści pokojową pracą i warkotem traktorów zagłuszymy podżegaczy wojennych, [...] wykażemy że zdecydowanie stoimy za pokojem, my traktorzyści w całości przyłączamy się do plebiscytu, do naszej Ojczyzny w imieniu przyszłości naszych dzieci”36. Jedna z uczennic na spotkaniu w szkole zapowiadała: „Walka o pokój to dla nas walka przeciwko tym, którzy chcą nam znów zniszczyć i odebrać zdobycze demokracji ludowej i wtrącić z powrotem w beznadziejną nędzę" ${ }^{37}$. Dziewczynka, która straciła ojca na wojnie, apelowała: „My małe dzieci nie chcemy tracić swych ojców i braci. My chcemy zawsze pokoju! Prosimy was rodzice, róbcie wszystko aby wojna nie wybuchła!"38. Pracownik jednego z zakładów w Opolu zapewniał: „Nasze podpisy będą ostrzejsze od bomby atomowej, będą wolą, która powstrzyma wojnę". Dosadnie wyraził swój protest jeden z ojców: „Nie po tom wychowywał synów, żeby z nich imperialiści robili mięso armatnie”39.

35 Tysiqce mieszkańców Opolszczyzny biorq udział w przygotowaniach do Plebiscytu Pokoju, „Trybuna Robotnicza" z 15 V 1951 r.; Najlepsza opinia w pracach przygotowawczych do Narodowego Plebiscytu Pokoju cieszy się dzielnicowy KOP Opole-Zaodrze, „Dziennik Zachodni”, z 16 V 1951 r.; W przygotowaniach do wielkiego plebiscytu, „Dziennik Zachodni”, z 16 V 1951 r.; Mieszkańcy Nysy pragnq pokoju aby odbudować swoje zniszczone miasto, „Dziennik Zachodni”, z 17 V 1951 r.; Z. Pocałun, Wielki dzień Paczkowa, „Trybuna Robotnicza”, z 22 V 1951 r.; Wszyscy ludzie pracy jednoczq się w narodowym froncie walki o pokój „Dziennik Zachodni”, z 15 V 1951 r.; APO, KP PZPR w Grodkowie, sygn. 43/VI/6, Sprawozdanie opisowe Powiatowego Komitetu z organizacji i przebiegu Narodowego Plebiscytu Pokoju na terenie powiatu grodkowskiego [1951 r.], nlb.; APO, KM PZPR w Opolu, sygn. 50/IV/3, Protokół z posiedzenia Egzekutywy KM PZPR w Opolu z 15 V 1951 r., k. 172-175.

36 APO, KP PZPR w Głubczycach, sygn. 42/II/1, Sprawozdanie Powiatowego Komitetu Obrońców Pokoju w Głubczycach [1951 r.], nlb.

37 J. Kamiński, Zadanie, które zostanie wykonane na piq̨tkę, „Trybuna Robotnicza”, z 20 V 1951 r.

38 Obchody Święta Ludowego z udziałem wicepremiera Korzyckiego, „Dziennik Zachodni”, z 15 V 1951 r.

39 APO, KW PZPR w Opolu, sygn. 1733, Ocena kampanii Narodowego Plebiscytu Pokoju przez Egzekutywę KW PZPR Opole [25 V 1951 r.], k. 130; AAN, KC PZPR w Warszawie, sygn. 237/VII-1678, Meldunek Referatu Sprawozdawczego KW PZPR w Opolu do KC PZPR w Warszawie z 18 V 1951 r., k. 42 . To samo zob.: APO, KW PZPR sygn. 1733, Meldunek KW PZPR w Opolu do KC PZPR w Warszawie z 17 V 1951 r., k. 107-109. 
Sporą wagę przywiązywano do bezpośrednich spotkań agitatorów pokoju z głosującymi. Jako szczególnie trafne wskazywano metody zastosowane w Brzegu, gdzie agitatorzy nie ograniczyli się do pozostawienia broszur i kart, lecz urządzili dyskusje z mieszkańcami na temat zagrożenia pokoju ${ }^{40}$. Zadaniem agitatora było skłonienie do udziału w plebiscycie i odparcie ewentualnych argumentów podważających jego zasadność. Agitatorzy mieli wpływać na tych, którzy ulegli obcym wpływom, i „otworzyć tym ludziom oczy na ludobójcze knowania anglosaskich imperialistów, przekonać ich o słusznej polityce naszego Rządu Ludowego i Partii" ${ }^{\prime 1}$. Jak argumentowano: „Trafna, przekonywująca odpowiedź agitatora pokoju to celny strzał w podżegaczy wojennych, strzał w ich kłamstwa i wrogą propagandę"42. Władze partyjne wyraźnie podkreślały, że udział w plebiscycie jest dobrowolny i wobec społeczeństwa „stanowczo nie wolno stosować żadnych form nacisku administracyjnego" ${ }^{43}$. $\mathrm{Z}$ tego też powodu zwracano uwagę na to, by agitacja była skuteczna.

$\mathrm{W}$ propagandowej retoryce przed plebiscytem wykorzystywano m.in. twierdzenie, że gwarantem światowego bezpieczeństwa jest obóz państw skupionych wokół ZSRR. Jako szczególne zagrożenie dla pokoju wskazywano Stany Zjednoczone i Wielką Brytanię oraz szeroko rozumianą grupę kapitalistów, którzy mieli liczyć na profity wynikające z potencjalnego konfliktu zbrojnego. Wobec przeciwnego obozu używano najczęściej określeń „podżegacze wojenni” i „imperialiści”. Jako dowód zbrodniczych tendencji USA przedstawiano udział tego państwa w wojnie koreańskiej. Chętnie też wskazywano, że Stany Zjednoczone są krajem wyzysku społecznego, w którym standardy życia przeciętnych obywateli są bardzo niskie. W województwie opolskim, gdzie w tym czasie wciąż żywe były sentymenty niemieckie, szczególnego znaczenia nabrały stosowane w kampanii odniesienia do Niemiec Zachodnich. Podpis pod Apelem berlińskim prezentowano jako wyraz sprzeciwu wobec działań mających na celu remilitaryzację RFN, odbudowę Wehrmachtu oraz zwolnienia z więzień nazistowskich generałów i zbrodniarzy wojennych. Działania te, jak przekonywano, godziły w pokój, ponieważ wynikały z dążeń rewizjonistycznych Niemiec Zachodnich planujących atak na polskie Ziemie Zachodnie ${ }^{44}$. Podkreślano, że wszyscy powinni podpisać karty, bo każdy jeden głos pod Apelem Światowej Rady Pokoju ma duże znaczenie. Zwracano uwagę na to, że akcja ma charakter masowy, a podobne są prowadzone również w innych krajach. Wielokrotnie przed

40 APO, WKOP, sygn. 1, Sprawozdanie z działalności politycznej i organizacyjnej Woj. Komitetu Obrońców Pokoju w Opolu i terenowych Komitetów Obrońców Pokoju za 1951 r., nlb.

41 Podpis na karcie plebiscytowej - to głos przeciwko wojnie, „Trybuna Robotnicza”, z 14 V 1951 r.

42 Ibidem.

43 APO, KP PZPR w Grodkowie, sygn. 43/VI/6, Sprawozdanie opisowe Powiatowego Komitetu z organizacji i przebiegu Narodowego Plebiscytu Pokoju na terenie powiatu grodkowskiego [1951 r.], nlb. Zob. też: APO, KW PZPR w Opolu, sygn. 988, Protokół z odprawy Wydziału Organizacyjnego [kwiecień 1951 r.], k. 32,38

44 Zob. np.: A.M., Śladami karty pokoju, „Trybuna Robotnicza”, z 22 V 1951 r.; APO, KP PZPR w Grodkowie, sygn. 43/VI/6, Sprawozdanie opisowe Powiatowego Komitetu z organizacji i przebiegu Narodowego Plebiscytu Pokoju na terenie powiatu grodkowskiego [1951 r.], nlb. 
plebiscytem argumentowano, że podpis pod Apelem berlińskim jest wyrazem akceptacji kierunku zmian politycznych i gospodarczych, które realizowane są w Polsce, a które wojna mogłaby przerwać. Kampanię plebiscytową zręcznie łączono z akcją upowszechniania planu sześcioletniego, wyjaśniając, że wzmożony wysiłek produkcyjny skutkuje poprawą kondycji i obronności kraju. Szczególnie chętnie sięgano do będącego de facto oksymoronem sloganu „walka o pokój”. Używano dość prostych haseł typu: „Kto pragnie szczęścia dla siebie i swoich bliskich złoży podpis pod apelem pokoju” lub „Wykonanie planu 6-letniego będzie najlepszą odpowiedzią na knowania imperialistów angloamerykańskich”, „Sława Bojownikom w walce o pokój!”, „Niech żyje Chorąży Pokoju Józef Stalin”, „Hańba podżegaczom wojennym, draniom ludu!"45.

W ramach prowadzonej kampanii dla uczczenia Narodowego Plebiscytu Pokoju podejmowano zobowiązania produkcyjne, zaciągano tzw. warty pokoju. Tego typu inicjatywy mające na celu wzmożenie wysiłku pracy były wówczas stałym elementem innych kampanii czy uroczystości, podejmowano je np. z okazji Międzynarodowego Dnia Kobiet, Święta Pracy, 22 Lipca itd. W akcję zobowiązań przed plebiscytem włączyły się przede wszystkim największe zakłady przemysłowe, spółdzielnie produkcyjne, państwowe gospodarstwa rolne, podejmowano też zobowiązania indywidualne lub gromadami. W ramach tych akcji załogi deklarowały przepracowanie dodatkowych godzin, wprowadzenie rozwiązań racjonalizatorskich, oszczędności. Na wsiach zapowiadano m.in. obsianie ugorów, zwiększenie dostaw mleka, oczyszczanie rowów melioracyjnych, porządkowanie obejść. Gros zobowiązań dotyczyło szybszego skończenia lub wcześniejszego podjęcia planowanych prac. Oficjalnie wartość deklarowanych prac dla uczczenia plebiscytu w województwie opolskim szacowano na $1 \mathrm{mln} \mathrm{z}^{46}$.

Kampania przed plebiscytem objęła również dzieci, które nie skończyły 15 lat, głównie uczniów. Przy zaangażowaniu komitetów rodzicielskich, a przede wszystkim nauczycieli, w szkołach organizowano kampanię, w której promowano hasła pokojowe. Przeprowadzano specjalne lekcje, na których przedstawiano założenia ideowe ruchu obrońców pokoju, przygotowywano gazetki ścienne o tematyce antywojennej" ${ }^{47}$. We wszystkich niemal szkołach uczniowie pisali wypracowania na temat Dlaczego

45 APO, KP PZPR w Grodkowie, sygn. 43/VI/6, Sprawozdanie opisowe Powiatowego Komitetu z organizacji i przebiegu Narodowego Plebiscytu Pokoju na terenie powiatu grodkowskiego [1951 r.], nlb.; Dzień Plebiscytu w Ślq̨skich Zakładach Obuwia w Otmęcie, „Trybuna Robotnicza”, z 20 V 1951 r.

46 AAN, KC PZPR, sygn. 237/VII-1696, Wewnętrzny Biuletyn Informacyjny Referatu Sprawozdawczego KW PZPR w Opolu z 14 V 1951 r.; APO, KW PZPR w Opolu, sygn. 1733, Ocena kampanii Narodowego Plebiscytu Pokoju przez Egzekutywę KW PZPR Opole [25 V 1951 r.], nlb.; Zobowiqzanie i apel racjonalizatorów Cementowni „Odra”, „Dziennik Zachodni”, z 9 V 1951 r.; Obchody Święta Ludowego z udziałem wicepremiera Korzyckiego, „Dziennik Zachodni”, z 15 V 1951 r.; J. Bałłaban, Młodzieżowe Warty Pokoju w Zakładach Przemysłu Dziewiarskiego w Głuchołazach, „Dziennik Zachodni”, z 17 V 1951 r.; Manifestacyjny udział społeczeństwa opolskiego w Narodowym Plebiscycie Pokoju, „Trybuna Robotnicza”, z 18 V 1951 r.; Będziemy utrwalać pokój, „Dziennik Zachodni”, z 14 V 1951 r.; 39 tys. aktywistów...; Plebiscyt - potężnq manifestacjq pokoju, „Dziennik Zachodni”, z 19 V 1951 r.; Plebiscyt zakończony - Warty Pokoju w ZPA trwaja nadal, „Trybuna Robotnicza”, z 23 V 1951 r.

47 AAN, KC PZPR, sygn. 237/VII-1696, Wewnętrzny Biuletyn Informacyjny Referatu Sprawozdawczego KW PZPR w Opolu z 14 V 1951 r.; Tysiqce mieszkańców Opolszczyzny biorq udział w przygotowaniach do Plebiscytu Pokoju, „Trybuna Robotnicza”, z 15 V 1951 r.; J. Kamiński, op. cit. 
walczymy o pokój - wybrane prace zostały opublikowane na łamach „Dziennika Zachodniego"18. Organizowano specjalne masówki dla szkół. I tak np. w Opolu 12 maja na pl. Armii Czerwonej (obecnie pl. Mikołaja Kopernika) manifestowały wszystkie szkoły, przechodząc później ulicami miasta ze szturmówkami i wznosząc okrzyki na cześć pokoju ${ }^{49}$. Młodsze klasy podejmowały rezolucje, w których zaznaczały swoje poparcie dla działań pokojowych, wypowiadały się przeciw wojnie bądź deklarowały, że ich wkładem w walkę o pokój będą dobre wyniki w nauce. Uczniowie szkoły podstawowej w Luboszycach w swej rezolucji pisali np.:

My młodzież szkolna w Luboszycach wraz z naszymi wychowawcami walczyć będziemy do ostatniego tchu o pokój i zwalczać podłe knowania imperialistów. Niech żyją narody zjednoczone w walce o pokój na czele ze Związkiem Radzieckim, „Niech żyje młodzież świata stojąca w pierwszych szeregach bojowników o pokój!”50.

W niektórych szkołach przeprowadzono oddzielne plebiscyty, aby i młodsi, wzorem starszych kolegów, mogli się wypowiedzieć przeciw wojnie. Samodzielnie przygotowane karty zebrali np. uczniowie szkół w Nowej Wsi Królewskiej i Grudzicach ${ }^{51}$. Działania te, choć prezentowano je jako spontaniczne, były de facto odgórnie sterowane, realizowane w myśl wytycznych partyjnych ${ }^{52}$. Angażowanie uczniów w kampanie miało na celu kształtowanie nie tylko ich postaw - dzieci miały hasła i przekazy ze szkoły przenosić do domu i nakłaniać do udziału w plebiscycie swych rodziców i najbliższe otoczenie ${ }^{53}$.

Istotnym elementem kampanii plebiscytowej był udział w niej duchownych. Władzom zależało na tym, by księża i zakonnice nie tylko złożyli swoje karty, ale także włączyli się $\mathrm{w}$ agitację ${ }^{54}$. Władze kościelne pozostawiły duchowieństwu swobodę w kwestii udziału w plebiscycie, zezwolono na ich udział w pracach KOP-ów, zakazując jedynie pracy w charakterze agitatorów pokoju ${ }^{55}$. W związku z tym przed plebiscytem w wielu kościołach podczas kazań nakłaniano wiernych do udziału

Dlaczego walczymy o pokój?, „Dziennik Zachodni”, z 18 V 1951 r.

50 AAN, KC PZPR, sygn. 237/VII-1696, Wewnętrzny Biuletyn Informacyjny Referatu Sprawozdawczego KW PZPR w Opolu z 22 V 1951 r.

51 Jak dzieci z Nowej Wsi Królewskiej podpisały Apel Pokoju, „Trybuna Robotnicza”, z 22 V 1951 r.

52 APO, KP PZPR w Głubczycach, sygn. 42/II/1, Sprawozdanie Powiatowego Komitetu Obrońców Pokoju w Głubczycach [1951 r.], nlb.

53 Zob.: wypowiedź Jana Paska z Wydziału Oświaty Prezydium Rady Narodowej w Raciborzu: APO KP PZPR w Raciborzu, sygn. 53/II/1, Protokół z posiedzenia plenum KP PZPR w Raciborzu z 14 V 1951 r., nlb.

54 Problem ten zasługuje na szersze omówienie, dlatego w tym miejscu zostanie tylko zasygnalizowany. 55 Archiwum Diecezjalne w Opolu, „Księża patrioci” w PRL, sygn.12/1, Pro memoria w sprawie akcji pokojowej [7 V 1951 r.], nlb. 
w plebiscycie i wypowiedzenia się przeciw wojnie. Na terenie województwa opolskiego w skład KOP-ów weszło 105 księży. Komitet pokojowy powstał nawet w opolskim seminarium duchownym. Wiele przykładów zaangażowania kleru w plebiscyt było opisywanych na łamach prasy, omawiano je też na zebraniach komitetów pokojowych oraz partyjnych ${ }^{56}$. Zważywszy na ówczesne napięte relacje między władzą a Kościołem, ta współpraca podczas Narodowego Plebiscytu Pokoju była czymś wyjątkowym. Z pewnością udział kleru w akcji wpłynął na postawy społeczeństwa i zdecydował w pewnej mierze o jej wynikach.

Ważne zadania upowszechniania idei Narodowego Plebiscytu Pokoju spoczęło na prasie. Doniesienia z województwa opolskiego dość obficie prezentowano na łamach „Trybuny Robotniczej” i „Dziennika Zachodniego”, tu też obszernie opisywano zarówno przygotowania, jak i przebieg plebiscytu. Artykuły na temat tej akcji przesiąknięte były duchem rywalizacji. W trakcie przygotowań informowano o postępach w zakładaniu KOP-ów, wskazywano regiony, gdzie akcja przebiegała najsprawniej, oraz wymieniano te, gdzie wypadała ona najgorzej. W dniach składania kart informowano o tym, ile już ich złożono, również podkreślając, które zakłady, gromady czy KOP-y zakończyły tę akcję jako pierwsze. Drukowano także informacje o harmonogramie szkoleń dla agitatorów, wieców czy emisji filmów dotyczących plebiscytu. Opisywano przebieg wieców, manifestacji oraz spotkań z agitatorami, które odbywały się $\mathrm{w}$ prywatnych mieszkaniach. Prezentowano sylwetki wyróżniających się pełnomocników KOP-ów i agitatorów ${ }^{57}$. Na łamach „Dziennika Zachodniego" publikowano cykl Przed Narodowym Plebiscytem Pokoju, w którym zamieszczano uzasadnienia osób z różnych środowisk o znaczeniu głosowania - wśród wypowiadających się był m.in. pochodzący z Opola Edmund Jan Osmań$\mathrm{Czyk}^{58}$. W opolskim dodatku „Trybuny Robotniczej” drukowano nadsyłane do redakcji listy mieszkańców województwa, będące odpowiedzią na pytanie Dlaczego podpiszę apel Światowej Rady Pokoju? Prezentowane wypowiedzi pochodziły od reprezentantów różnych grup społecznych - robotników, chłopów, studentów,

56 APO, KW PZPR w Opolu, sygn. 1733, Ocena kampanii Narodowego Plebiscytu Pokoju przez Egzekutywę KW PZPR Opole [25 V 1951 r.], nlb.; AAN, KC PZPR w Warszawie, sygn. 237/VII-1678, Meldunek sytuacyjny w związku z Plebiscytem Pokoju na terenie województwa opolskiego z 17 V 1951 r., k. 41 ; APO, KM PZPR w Opolu, sygn. 50/IV/4, Ocena sytuacji politycznej na terenie miasta Opola w m-cu maju 1951 r., k. 430; Duchowieństwo opolskie w obronie pokoju, „Trybuna Robotnicza”, z 14 V 1951 r.; W. Kaniak, Ksiqdz - patriota, „Trybuna Robotnicza”, z 21 V 1951 r.; Duchowieństwo i działacze katoliccy Opolszczyzny właczyli się do walki o pokój, „Trybuna Robotnicza”, z 24 V 1951 r.; Katolicy polscy jednocza się wokół żadań Narodowego Plebiscytu Pokoju, „Trybuna Robotnicza”, z 20 V 1951 r. (to samo w: Ogólnopolska konferencja intelektualistów i działaczy katolickich, „Dziennik Zachodni”, z 20 V 1951 r.).

57 Wszyscy ludzie pracy jednoczq się w narodowym froncie walki o pokój, „Dziennik Zachodni”, z $15 \mathrm{~V}$ 1951 r.; Agitatorzy pokoju w akcji, „Trybuna Robotnicza” z 16 V 1951 r.; Wszyscy podpiszemy Apel Pokoju, „Trybuna Robotnicza”, z 15 V 1951 r.; Aby już nigdy żołdak faszystowski nie zabijał dzieci, „Trybuna Robotnicza”, z 17 V 1951 r.; Sportowcy Opolszczyzny wezma udział w Plebiscycie, „Trybuna Robotnicza”, z 16 V 1951 r.; Komitety Obrońców Pokoju dekorują lokale głosowania w gromadach pow. namysłowskiego, „Dziennik Zachodni”, z 14 V 1951 r.; Opolszczyzna w pełni przygotowana do należytego przeprowadzenia Plebiscytu Pokoju, „Dziennik Zachodni”, z 10 V 1951 r.; Pamiętny dzień Czerwieńcic, „Trybuna Robotnicza”, z 21 V 1951 r.; Plebiscyt - potężnq manifestacjq pokoju, „Dziennik Zachodni”, z 19 V 1951 r.; Złożyli podpisy pod Apelem Pokoju gdyż chcq się uczyć i brać udział w twórczej pracy, „Trybuna Robotnicza”, z 18 V 1951 r. 
duchownych, inteligencji, gospodyń domowych, sportowców ${ }^{59}$. W głosach tych powtarzały się apele o to, by wszyscy podpisali Apel Światowej Rady Pokoju, potępiano dążenia wojenne „amerykańskich imperialistów”, podkreślano zasługi ZSRR dla ruchu obrońców pokoju. Cytowano m.in. wypowiedzi rodzimych mieszkańców regionu, którzy potępiali militaryzację Niemiec Zachodnich i „penetrację kapitału anglo-amerykańskiego" w tym kraju ${ }^{60}$. Przedwojenny działacz polski wspominający powstania śląskie i głosowanie z 1921 r. przekonywał: „Walka o pokój to walka z tym samym międzynarodowym kapitalizmem Niemiec, Anglii czy Ameryki, który oszukał nas w plebiscycie śląskim". Inny autochton występował jako rzecznik sukcesów polskiej władzy na Śląsku: „Są wrogowie, którzy twierdzą, że robotnik i chłop polski nie potrafią niczego dokonać, że tylko dużo potrafili zrobić panowie niemieccy". Jego zdaniem osobom tym należy pokazywać sukcesy władzy polskiej na Śląsku, znaczenie planu 6-letniego, bo dzięki temu „zrozumieją jak ważny jest pokój”61.

W kampanii przed plebiscytem wykorzystano też film. Od 9 maja wyświetlano w województwie opolskim Popieramy i podpisujemy Apel Światowej Rady Pokoju. Prezentowano go bezpłatnie, zazwyczaj na wolnym powietrzu, zarówno w miastach, jak i małych miejscowościach oraz w spółdzielniach produkcyjnych. Zaplanowano tych emisji ponad 200. Wyświetlano też inne materiały, głównie obrazy nt. osiągnięć gospodarczych i kulturalnych po wojnie w województwie opolskim. Każdy seans był poprzedzony wystąpieniem agitatora, który wyjaśniał znaczenie i cele plebiscytu ${ }^{62}$. Z inicjatywy Wydziału Propagandy opolskiego KW PZPR przybyła na teren województwa ekipa Filmu Polskiego, która nagrała przebieg składania kart w Wójtowej Wsi pod Opolem. Materiał ten później stał się częścią jednego z odcinków Polskiej Kroniki Filmowej ${ }^{63}$.

W miastach do popularyzowania plebiscytu wykorzystano również radiowęzły, przez które emitowano hasła pokojowe i apele o składanie kart, a później także wyniki głosowania. Dla uczczenia plebiscytu w kędzierzyńskich Zakładach Przemysłowo Azotowych od 15 maja, codziennie na innym oddziale koncertowała orkiestra 
zakładowa ${ }^{64}$. W Głubczycach 13 maja zaplanowano przejazd członków ZMP rowerami udekorowanymi hasłami pokojowymi ${ }^{65}$. Na wsi aktywnie $\mathrm{w}$ przygotowaniach brały udział ekipy łączności miasta ze wsią.

Oprawę plebiscytowi nadawały specjalne dekoracje. Eksponowano głównie plakaty i hasła promujące pokój, portrety i cytaty z wypowiedzi Bolesława Bieruta oraz „chorążego pokoju” Józefa Stalina, wywieszano transparenty, a także flagi (głównie czerwone). Częstym motywem plebiscytowej scenografii był biały gołąbek pokoju. Zdobiono przede wszystkim punkty, w których składano karty, a także świetlice, lokale, wystawy sklepowe, stanowiska pracy, budynki urzędów, szkół, zakłady pracy, rzadziej domy prywatne. Jak zaznaczano, dekoracje przygotowane na plebiscyt były lepsze niż te organizowane kilka tygodni wcześniej na 1 Maja. Szczególnie ładnie przyozdobione były punkty KOP w Chrząstowicach, Maciejowicach, Więcmierzycach, niektóre w Brzegu, Strzelcach Opolskich, Opolu oraz świetlicy Towarzystwa Przyjaźni Polsko-Radzieckiej w Grodkowie i świetlicy Ligi Kobiet w Otmuchowie. Dekoracje były barwne i pomysłowe, wykonywane niewielkim kosztem - wykorzystywano np. kwiaty, a gołąbki wycinano z makulatury. Z braku transparentów czy plakatów hasła plebiscytowe malowano $\mathrm{w}$ niektórych przypadkach wprost na budynkach. Bogato przyozdobiono za to np. Zakłady Przemysłu Azotowego „Kędzierzyn", gdzie nad bramą wejściową zainstalowano napis Narodowy Plebiscyt Pokoju 17 V 1951 - Podpisujemy wszyscy Apel Światowej Rady Pokoju, a vis-à-vis budynku administracji ustawiono Wieżę Pokoju z potężnym globusem, który okrążały dwa białe gołębie, poruszane specjalnym mechanizmem ${ }^{66}$. Warto zaznaczyć, że specyfika regionu opolskiego wymagała pewnego wyczucia i staranności w doborze motywów dekoracji. Popłoch wywołały np. rozwieszone w powiecie oleskim plakaty przedstawiające niemiecki Wehrmacht - rozwieszono je bez konsultacji z Wydziałem Propagandy KP PZPR, który nakazał jak najszybciej je zdjąć67.

Propaganda plebiscytowa swoje apogeum osiągnęła 16 maja. Na ten dzień we wszystkich zakładach pracy zaplanowano masówki, podczas których załogi podejmowały

Plebiscyt - potężnq manifestacjq pokoju, „Dziennik Zachodni”, z 19 V 1951 r.

65 APO, KP PZPR w Głubczycach, sygn. 42/II/1, Sprawozdanie Powiatowego Komitetu Obrońców Pokoju w Głubczycach [1951 r.], nlb.

66 APO, KW PZPR w Opolu, sygn. 1733, Ocena kampanii Narodowego Plebiscytu Pokoju przez Egzekutywę KW PZPR Opole [25 V 1951 r.], nlb.; ibidem, sygn. 248, Informacja w sprawie przebiegu kampanii plebiscytowej z 18 V 1951 r., k. 77; APO, KP PZPR w Raciborzu, sygn. 53/II/1, Sprawozdanie przebiegu plebiscytu narodowego na terenie Raciborza, nlb.; APO, KP PZPR w Grodkowie, sygn. 43/VI/6, Sprawozdanie opisowe Powiatowego Komitetu z organizacji i przebiegu Narodowego Plebiscytu Pokoju na terenie powiatu grodkowskiego [1951 r.], nlb.; APO, KM PZPR w Opolu, sygn. 50/IV/3, Sprawozdanie z akcji przygotowawczej i przebiegu Ogólnopolskiego Plebiscytu Pokoju w Opolu [1951 r.], k. 73-77; AAN, KC PZPR w Warszawie, sygn. 237/VII-234, Sprawozdanie z wyjazdu służbowego do woj. opolskiego z 28 V 1951 r. k. 36, 38; Plebiscyt - potężna manifestacja pokoju, „Dziennik Zachodni”, z 19 V 1951 r.; Opolszczyzna uroczyście powita dzień Plebiscytu Pokoju, „Trybuna Robotnicza”, z 16 V 1951 r.; Powiat namysłowski żyje sprawq obrony pokoju, „Trybuna Robotnicza”, z 20 V 1951 r.; Za pokojem - przeciw podżegaczom wojennym..., „Trybuna Robotnicza”, z 20 V 1951 r.; Wielkie dni Plebiscytu Pokoju na Opolszczyźnie, „Trybuna Robotnicza", z 20 V 1951 r.

67 APO, KP PZPR w Oleśnie, sygn. 49/IV/5, Sprawozdanie z przebiegu akcji plebiscytowej na terenie powiatu oleskiego, nlb. 
rezolucje o tym, że wspólnie, manifestacyjnie złożą karty w Narodowym Plebiscycie Pokoju. Wieczorem zorganizowano capstrzyki dla młodzieży, występy artystyczne w świetlicach, prelekcje, śpiewano pieśni o pokoju przed punktami KOP-ów. W Opolu na 16 maja zaplanowano w Państwowym Teatrze Ziemi Opolskiej wiec inteligencji pracującej. Dla młodzieży zorganizowano ognisko i występy zespołów artystycznych na pl. Ferdinanda Focha (obecnie Józefa Piłsudskiego). W niektórych miastach (np. Opolu, Strzelcach Opolskich, Prudniku i Głubczycach) wiece i capstrzyki zamieniały się w „spontaniczne manifestacje”. Podobnie było w Grodkowie, gdzie według sprawozdania tamtejszego KOP-u „młodzież i robotnicy przechodząc w marszu skandowali «Pokój, Stalin, Bierut»”68.

\section{Głosowanie}

Na terenie województwa opolskiego uruchomiono 3311 punktów, w których można było oddać karty (199 w miastach, $993 \mathrm{w}$ gromadach, $1103 \mathrm{w}$ zakładach pracy, 632 w szkołach, 269 w urzędach, 102 w spółdzielniach, 13 w Państwowych Ośrodkach Maszynowych) ${ }^{69}$. Punkty te nie powinny były znajdować się $w$ budynkach administracyjnych, dlatego urządzano je najczęściej w szkołach, świetlicach, a w niektórych okręgach nawet w prywatnych mieszkaniach ${ }^{70}$. Choć pierwotnie zakładano, że mieszkańcy wsi wezmą udział w plebiscycie przede wszystkim w niedzielę 20 maja, okazało się, że najwięcej głosów zebrano w ciągu dwóch pierwszych dni - 17 maja udział w plebiscycie wzięło $60 \%$ uprawnionych, a nazajutrz liczba ta sięgnęła $77 \%$. Z terenu województwa meldowano, że ustalone harmonogramy głosowania zostały zaburzone, ponieważ wiele osób pojawiło się z kartami wcześniej. Pod niektórymi punktami gromadzono się niemal od świtu. Najwcześniej, bo już 18 maja, zbieranie kart zakończono w powiecie grodkowskim, następnego dnia w niemodlińskim. Najwcześniej, już ok. 8.00 rano 17 maja, komplety głosów zebrano w Żerkowicach i Radomirowicach ${ }^{71}$. Według oficjalnych doniesień i sprawozdań mieszkańcy województwa brali udział w plebiscycie „chętnie, dobrowolnie, radośnie, przeważnie manifestacyjnie”. Do punktów głosowania stawali w niektórych przypadkach wszyscy mieszkańcy gromady. Wspólnie karty składali pracownicy PGR-ów oraz załogi

68 APO, KP PZPR w Grodkowie, sygn. 43/VI/6, Sprawozdanie opisowe Powiatowego Komitetu z organizacji i przebiegu Narodowego Plebiscytu Pokoju na terenie powiatu grodkowskiego [1951 r.], nlb. O masówkach z 16 maja zob. też AAN, KC PZPR w Warszawie, sygn. 237/VII-234, Sprawozdanie z wyjazdu służbowego do woj. opolskiego z 28 V 1951 r., k. 39; APO, KW PZPR w Opolu, sygn. 1733, Ocena kampanii Narodowego Plebiscytu Pokoju przez Egzekutywę KW PZPR Opole [25 V 1951 r.], nlb.; APO, KM PZPR w Opolu, sygn. 50/IV/3, Sprawozdanie z akcji przygotowawczej i przebiegu Ogólnopolskiego Plebiscytu Pokoju w Opolu [1951 r.], k. 73-77; Tysiace mieszkańców Opolszczyzny biorq udział w przygotowaniach do Plebiscytu Pokoju, „Trybuna Robotnicza” z 15 V 1951 r.; Wielki wiec inteligencji pracującej, „Dziennik Zachodni", z 18 V 1951 r.

Plebiscyt na Opolszczyźnie - zakończony, „Trybuna Robotnicza”, z 23 V 1951 r.

70 APO, KP PZPR w Raciborzu, sygn. 53/II/1, Sprawozdanie przebiegu plebiscytu narodowego na terenie Raciborza, nlb.; W przygotowaniach do wielkiego plebiscytu, „Dziennik Zachodni”, z 16 V 1951 r.

71 APO, KW PZPR w Opolu, sygn. 1816, Sprawozdanie z kontroli powiatu opolskiego po linii Narodowego Plebiscytu jak również szkolenia partyjnego od dnia 12-19 V 1951 r., k. 51-52; Pierwszy meldunek plebiscytowy z woj. opolskiego, „Dziennik Zachodni”, z 18 V 1951 r. 
w zakładach pracy. Idea plebiscytu spotkała się także z uznaniem gości z zagranicy: „Fakt należytego zrozumienia walki o pokój doceniły dwie Niemki, przebywające w gościnie u znajomych na terenie gminy Kuźnia Raciborska, które nie rozumiejąc języka polskiego przyszły do komitetu gminnego KOP i poprosiły o kartki i podpisały je"72.

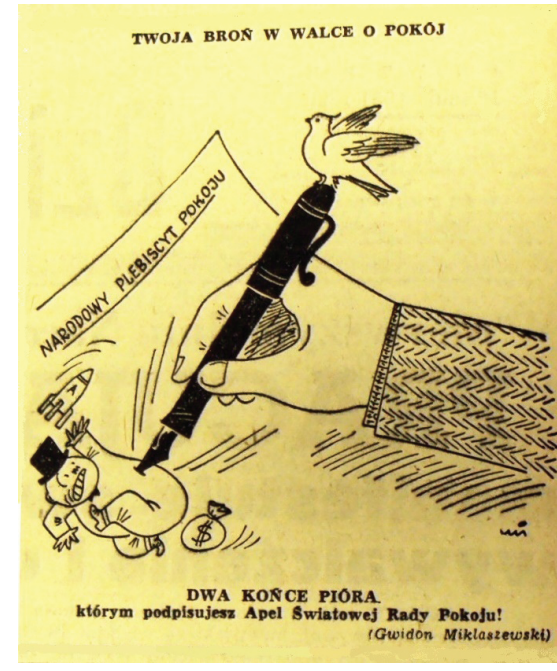

Il. 2. Rysunek satyryczny

Gwidona Miklaszewskiego

dotyczący Narodowego

Plebiscytu Pokoju.

„Dziennik Zachodni”,

z 18 V $1951 \mathrm{r}$.

Moment głosowania miał przebiegać w uroczystej atmosferze, dlatego w wielu przypadkach towarzyszyły mu śpiewy, koncerty czy deklamacje (w jednej z miejscowości urządzono występy grupy baletowej), przygotowywane najczęściej przez szkolne lub świetlicowe zespoły artystyczne. Niektóre z załóg, głównie ze spółdzielni produkcyjnych lub PGR-ów, przybywały na głosowanie udekorowanymi zielenią i hasłami pokojowymi wozami lub formując manifestacyjne pochody. Przemarsze ze szturmówkami, podczas których wypuszczano gołębie lub skandowano hasła na cześć pokoju i Stalina, zorganizowano np. w Tułowicach, Większycach, Karłowicach, Rybnej, Trzebieszowicach, Modzurowie i Czerwińczycach ${ }^{73}$. Wraz z rozpoczęciem plebiscytu w niektórych miastach urządzono manifestacje młodzieżowe, np. uczniowie pikietowali rano pod ratuszem w Namysłowie, a w Koźlu zorganizowali pochód z transparentami, karykaturami i szturmówkami ${ }^{74}$. W niektórych

72 APO, KP PZPR w Raciborzu, sygn. 53/II/1, Protokół z posiedzenia plenum KP PZPR w Raciborzu z 22 V 1951 r., nlb. Podobny przypadek zanotowano także w Biedrzychowicach, APO, KW PZPR w Opolu, sygn 1733, Ocena kampanii Narodowego Plebiscytu Pokoju przez Egzekutywę KW PZPR Opole [25 V 1951 r.], k. 131.

73 APO, KP PZPR w Raciborzu, sygn. 53/II/1, Sprawozdanie z przebiegu plebiscytu narodowego na terenie Raciborza, nlb.; S. Ostrowski, Manifestacyjny przebieg Plebiscytu w powiecie kozielskim, „Trybuna Robotnicza”, z 22 V 1951 r.; Składanie kart plebiscytowych na Opolszczyźnie wspaniałq manifestacja pokojowa, „Trybuna Robotnicza”, z 22 V 1951 r.; Pierwszy dzień Narodowego Plebiscytu Pokoju na Opolszczyźnie, „Dziennik Zachodni”, z 18 V 1951 r

74 Plebiscyt-potężnq manifestacjq pokoju, „Dziennik Zachodni”, z 19 V 1951 r.; Powiat namysłowski żyje sprawq obrony pokoju, „Trybuna Robotnicza”, z 20 V 1951 r. 
miastach,np. Opolu i Raciborzu, na popołudnie przygotowano występy artystyczne, a w Głubczycach pokazy gimnastyczne. Na wsiach zorganizowano zabawy ludowe ${ }^{75}$.

Doniesienia prasowe na temat przebiegu plebiscytu były pełne entuzjazmu i dowodów poparcia społecznego dla jego idei, pomijano całkowicie informacje na temat osób, które w głosowaniu nie brały udziału. Podawano za to szczegółowe dane dotyczące liczby zebranych kart z poszczególnych powiatów, podkreślając, gdzie udało się już zebrać $100 \%$ głosów. Informowano o tym, jak głosowały zakłady pracy, poszczególne grupy zawodowe (np. rzemieślnicy, adwokaci), wymieniano także uczestniczących w plebiscycie duchownych. Wyniki głosowania emitowano również przez radio. Specjalny program z okazji plebiscytu przygotowały radiowęzły - odpowiednio dobrany repertuar muzyczny był wzbogacany pogadankami na temat pokoju oraz danymi o liczbie zebranych kart. W Paczkowie komunikaty o przebiegu głosowania emitowano z zaopatrzonych w megafony samochodów, które krążyły po mieście w pierwszy dzień plebiscytu ${ }^{76}$.

Szczególny przebieg miał wyznaczający koniec głosowania 22 maja. Dla uczczenia zakończenia plebiscytu urządzono imprezy artystyczne. Na przykład specjalny program (przy bardzo małej frekwencji) zaprezentowano w Państwowym Teatrze Ziemi Opolskiej. Występy szkolnych zespołów artystycznych urządzono także np. w parku miejskim w Namysłowie. Przyjmowanie kart oficjalnie zakończono o godz. 15.00. Po zebraniu blankietów z całego powiatu spod siedzib PKOP-ów przewożono je samochodami do Opola. Auta były specjalnie udekorowane kwiatami oraz transparentami z napisami „Wykonując Plan Sześcioletni walczymy o pokój”, „Światowy Obóz Pokoju zwycięży", a np. w Namysłowie zdobił je rysunek chłopa z sierpem i robotnika z młotem. Moment odwożenia kart do stolicy województwa stał się pretekstem do zorganizowania $\mathrm{w}$ miastach powiatowych pokojowych manifestacji. Delegacje odjeżdżające do Opola były żegnane przez grupy ze szturmówkami i transparentami. Szczególnie uroczyście wyglądało to w Namysłowie. Wzdłuż całej trasy, którą jechał samochód z kartami, ustawiły się delegacje młodzieży i robotników wiwatujących na cześć pokoju. Samochód zatrzymywano na granicy każdej gminy, dekorowano dodatkowymi kwiatami, skandowano za nim „Pokój! Pokój!”. Do wieczora 22 maja głosy ze wszystkich powiatów trafiły do opolskiego WKOP. Do swoich kart specjalny list dla PKOP-u dołączyło społeczeństwo Głogówka. Karty z powiatu kluczborskiego

75 APO, KP PZPR w Głubczycach, sygn. 42/II/1, Sprawozdanie Powiatowego Komitetu Obrońców Pokoju w Głubczycach [1951 r.], nlb.; 450 tysięcy kart plebiscytowych złożyła już ludność Opolszczyzny, „Dziennik Zachodni”, z 20 V 1951 r.; Akcja plebiscytowa zakończona, „Dziennik Zachodni”, z 25 V 1951 r.

76450 tysięcy kart plebiscytowych złożyła już ludność Opolszczyzny, „Dziennik Zachodni”, z 20 V 1951 r.; Pierwszy dzień Narodowego Plebiscytu Pokoju na Opolszczyźnie, „Dziennik Zachodni”, z 18 V 1951 r.; Plebiscyt Pokoju na Opolszczyźnie manifestacja jedności całego społeczeństwa, „Trybuna Robotnicza”, z 19 V 1951 r.; Rzemieślnicy opolscy stajq w szeregach obrońców pokoju biorqc gremialny udział w Plebiscycie, „Trybuna Robotnicza”, z 19 V 1951 r.; Plebiscyt Pokoju na Opolszczyźnie manifestacja jedności całego społeczeństwa, "Trybuna Robotnicza”, z 19 V 1951 r.; Inteligencja pracujaca Opolszczyzny biorac udział w Plebiscycie walczy o pokój i rozwój kultury, „Trybuna Robotnicza”, z 19 V 1951 r.; Pierwszy meldunek plebiscytowy z woj. opolskiego, „Dziennik Zachodni”, z 18 V 1951 r.; APO, KP PZPR w Grodkowie, sygn. 43/VI/6, Sprawozdanie opisowe Powiatowego Komitetu z organizacji i przebiegu Narodowego Plebiscytu Pokoju na terenie powiatu grodkowskiego [1951 r.], nlb.; APO, KM PZPR w Opolu, sygn. 50/IV/3, Sprawozdanie z akcji przygotowawczej i przebiegu Ogólnopolskiego Plebiscytu Pokoju w Opolu [1951 r.], k. 73-77. 
złożono w specjalnej skrzyni „z ciemnopoliturowanego drewna z białym gołębiem na niebieskim wieku"77. Z WKOP-u w Opolu karty po przesortowaniu i przygotowaniu do dalszego transportu wysłano do Warszawy.

Zarówno podczas kampanii przed głosowaniem, jak i w dniach zbierania kart pojawiły się pewne kłopotliwe kwestie dotyczące przebiegu plebiscytu. Starsze pokolenie ludności rodzimej w akcji tej szukało analogii do plebiscytu z $1921 \mathrm{r}$. W związku z tym zadawali pytania o to, dlaczego karta jest tylko jedna, a nie dwie, tak by móc wypowiedzieć się nie tylko „za”, ale i „przeciw”78. Pojawiła się także uwaga, że apele kierowane o masowy udział w plebiscycie do Polaków nie dotyczą rodzimych Ślązaków, którzy nie mają oficjalnie polskiego obywatelstwa, tylko posiadają jedynie tymczasowe zaświadczenia $^{79}$. Negatywnie wypowiadano się o jawności głosowania, kwestionowano także jego dobrowolność, niektórzy wyraźnie przyznawali, że składają karty w obawie przed szykanami, które mogłyby ich spotkać, gdyby tego nie dopełnili ${ }^{80}$.

Na niektórych kartach zamieszczano dopiski. Część z głosujących dodawała własne hasła antywojenne. Znajdowały się też nieco szersze wypowiedzi, np.: „Apel sztokholmski nie podpisałem bo uwierzyłem wrogiej propagandzie, teraz podpisuję kartę plebiscytową bo się przekonałem, że tylko walka o pokój daje mi możność życia"81. Nie brakowało odważnych, którzy na podpisanych kartach wpisywali swoje osobiste bolączki. Najczęściej były to uwagi o chęci wyjazdu do Niemiec, w celu połączenia się z rodziną ${ }^{82}$. W Dzierżoniowie dwie osoby na odwrocie kart zapisały pierwotny tekst w tłumaczeniu niemieckim, opuszczając frazę „W imię niepodległości polskiej" i tam złożyły swój podpis. Na niektórych kartach pojawiały się adnotacje głosujących, że podpis składają jako Niemcy ${ }^{83}$.

Wbrew lansowanemu przekazowi, że Narodowy Plebiscyt Pokoju spotkał się z bezwzględnym i całkowitym poparciem społecznym, odnotowywano głosy społecznego sprzeciwu wobec tej akcji. Aparat bezpieczeństwa monitorował nastroje społeczne

77 Triumfalna droga kart plebiscytowych, „Trybuna Robotnicza”, z 24 V 1951 r.; Plebiscyt pokoju zakończony na terenie woj. opolskiego, „Dziennik Zachodni”, z 24 V 1951 r.

78 APO, KW PZPR w Opolu, sygn. 248, Protokół nr 20/51 z posiedzenia Egzekutywy KW PZPR w Opolu z 18 V 1951 r., k. 74-79; AAN, KC PZPR w Warszawie, sygn. 237/VII-234, Sprawozdanie z wyjazdu służbowego do woj. opolskiego z 28 V 1951 r., k. 36.

79 Archiwum Instytutu Pamięci Narodowej - Oddział we Wrocławiu (dalej: AIPN Wr), sygn. 07/328, t. 1, k. 288, Szef PUBP w Koźlu do Szefa WUBP w Opolu z 5 VI 1951 r., s. 3. Dokumenty ze zbiorów AIPN Wr wykorzystałam dzięki uprzejmości i wskazówkom Dariusza Misiejuka, za co serdecznie mu dziękuję.

80 Ibidem, 07/67, k. 26, PUBP w Głubczycach do Szefa WUBP w Opolu z 6 VI 1951 r., s. 2.

81 AAN, KC PZPR w Warszawie, sygn. 237/VII-234, Sprawozdanie z wyjazdu służbowego do woj. opolskiego z 28 V 1951 r., k. 41.

82 APO, KW PZPR w Opolu, sygn. 248, Protokół nr 21/51 z posiedzenia Egzekutywy KW PZPR w Opolu z 25 V 1951 r., k. 89; APO, KP PZPR w Raciborzu, sygn. 53/II/1, Protokół z posiedzenia plenum KP PZPR w Raciborzu z 22 V 1951 r., nlb.; APO, KP PZPR w Oleśnie, sygn. 49/IV/5, Protokół z posiedzenia egzekutywy KP PZPR w Oleśnie z 22 V 1951 r., nlb.; Wielkie dni Plebiscytu Pokoju na Opolszczyźnie, „Trybuna Robotnicza", z 20 V 1951 r.

83 APO, KP PZPR w Kluczborku, sygn. 44/V/3, Protokół z odprawy aktywu partyjnego z 22 V 1951 r., s. 4.; ibidem, sygn. 44/VI/4, Meldunek z posiedzenia aktywu KP PZPR Kluczbork z 22 V 1951 r. 
w trakcie plebiscytu, przyglądając się m.in. środowisku byłych członków Armii Krajowej czy autochtonom o nastawieniu antypolskim i proniemieckim. Efekty tych działań były jednak analizowane wyłącznie w zamkniętych gremiach partyjnych. Władze przyznawały, że w czasie akcji plebiscytowej pojawiły się liczne nieprzyjazne wypowiedzi w sprawie panującego w Polsce ustroju. „Są jednak i tacy osobnicy, którzy wprawdzie wojny nie chca, ale pragnęliby pokoju innego, to jest w innym ustroju" ${ }^{84}$. Jako środowiska, które generowały nieprzyjazny klimat, wskazywano bogatych rolników, kułaków, którzy w opinii władz wraz z potencjalną wojną liczyli na zmianę ustroju, tzn. powrót kapitalizmu. Wśród odnotowanych wrogich wypowiedzi pojawiały się np. takie, które wskazywały, że to członkowie polskich władz „są pierwsi którzy chcą wojny, gdyż gnębią ludzi podatkami a nie dają mieszkań ani chleba”. Inny przykład „przemyślanej i wyrafinowanej roboty wroga wśród ludzi pracy" pochodził z Namysłowa, gdzie stwierdzono, że akcje takie jak Narodowy Plebiscyt Pokoju nie wyciszą nastrojów społecznych i ludzie zbuntują się przeciwko władzy, o ile znajdą się liderzy, którzy nimi pokierują ${ }^{85}$. Na zebraniu gromadzkim w Królowej w pow. głubczyckim jeden z zebranych sugerował zmianę treści plebiscytu: „Aby się wszyscy podpisali, ale w tym celu żeby Związek Radziecki oddał nam tereny wschodnie” ${ }^{\text {"6 }}$. Niektórzy wątpili w skuteczność plebiscytu, ponieważ „wojna i tak będzie", a Niemcy Zachodnie sa zdeterminowane na odebranie utraconych po II wojnie światowej terenów ${ }^{87}$. Pojawiły się również sporadycznie hasła antyplebiscytowe, np.: „Niech żyje Ameryka”, „Wojna musi być”, „Walczymy o pokój z pustymi żołądkami"88. Napisy i ulotki w języku niemieckim podważające głosowanie pojawiły się m.in. w Radawiu i Kalinowicach ${ }^{89}$. W Paczkowie do tamtejszego KOP-u wysłano anonim nawołujący do wojny, podpisany przez Oddział Partyzancki nr 3390. Na murze jednego z zakładów w Brzegu pojawił się napis: „Plebiscyt to ostatnia deska

84 APO, KP PZPR w Raciborzu, sygn. 53/II/1, Protokół z posiedzenia plenum KP PZPR w Raciborzu z 14 V 1951 r., nlb. APO, WKOP, sygn. 1, Sprawozdanie z działalności politycznej i organizacyjnej Woj. Komitetu Obrońców Pokoju w Opolu i terenowych Komitetów Obrońców Pokoju za 1951 r. nlb.

85 APO, KW PZPR w Opolu, sygn. 1733, Ocena kampanii Narodowego Plebiscytu Pokoju przez Egzekutywę KW PZPR Opole [25 V 1951 r.], k. 124-125.

86 AIPN Wr, sygn. 07/67, k. 26, PUBP w Głubczycach do Szefa WUBP w Opolu z 6 VI 1951 r., s. 2.

87 APO, KP PZPR w Koźlu, sygn. 45/VIII/1, Protokół z odprawy kierowników Grup Agitatorów z powiatu kozielskiego z 11 V 1951 r., nlb; AIPN Wr, sygn. 07/370, k. 67, Szef PUBP w Brzegu do Naczelnika Wydziału III WUBP w Opolu z 29 V 1951 r., s. 3; ibidem, k. 123; Szef PUBP w Brzegu do Naczelnika Wydziału III WUBP w Opolu z 30 V 1951 r., s. 1; ibidem, sygn. 07/328, t. 1, k. 288, Szef PUBP w Koźlu do Szefa WUBP w Opolu z 5 VI 1951 r., s. 3; ibidem, sygn. 07/446, t. 1, k. 30, Szef PUBP w Nysie do Szefa WUBP w Opolu z 4 VI 1951 r. s. 3.

88 APO, KW PZPR w Opolu, sygn. 248, Protokół nr 21/51 z posiedzenia Egzekutywy KW PZPR w Opolu z 25 V 1951 r., k. 89; AIPN Wr, sygn. 07/45, k. 30, Szef PUBP w Strzelcach Opolskich do Szefa WUBP w Opolu z 4 VI 1951 r., s. 2.

89 AIPN Wr, sygn. 07/469, t. 1, PUBP w Oleśnie do Szefa WUBP w Opolu z 4 VI 1951 r.; ibidem, sygn. 07/45, k. 30, Szef PUBP w Strzelcach Opolskich do Szefa WUBP w Opolu z 4 VI 1951 r., s. 2.

90 Ibidem, sygn. 07/446, t. 1, k. 31, Szef PUBP w Nysie do Szefa WUBP w Opolu z 4 VI 1951 r., s. 4 
ratunku dla ZSRR" ${ }^{\prime 1}$. Ulotki nakłaniające do bojkotu plebiscytu znaleziono w budynku opolskiej Wojewódzkiej Rady Narodowej i w zakładach w Zdzieszowicach ${ }^{92}$. Obserwowano też zrywanie plakatów plebiscytowych ${ }^{93}$. Do bojkotu głosowania mieli namawiać niektórzy z mieszkańców województwa opolskiego, którzy starali się o zgodę na wyjazd na stałe do Niemiec. Zdarzenia te miały charakter incydentalny, nie przybrały szerszego wymiaru - tak wynika z raportów aparatu bezpieczeństwa oraz sprawozdań komitetów pokojowych i partyjnych. Wobec sporadycznych, ale odnotowywanych wrogich wystąpień UBP przestrzegal, by nie „upajać się osiągnięciami", i zalecał wzmożoną czujność, by nic nie zakłóciło właściwego przebiegu plebiscytu ${ }^{94}$. Środowiska i jednostki, które wypowiadały się przeciw głosowaniu, aparat bezpieczeństwa otaczał siecią agenturalną i informatorami ${ }^{95}$.

Narodowemu Plebiscytowi Pokoju towarzyszyły różne plotki, wypaczające jego sens i mające na celu zniechęcić do udziału w nim. W województwie opolskim krążyły pogłoski o tym, że plebiscyt jest głosowaniem za tym, by przekształcić Polskę w kolejną republikę ZSRR ${ }^{96}$. Parafowanie karty miało oznaczać akceptację planu sześcioletniego lub akces do spółdzielni produkcyjnej. Obawiano się, że podpisanie Apelu berlińskiego będzie skutkowało wywiezieniem w głąb ZSRR lub uniemożliwieniem wyjazdu do Niemiec osobom, które się o to ubiegają. Krążyły też opinie, że udział w plebiscycie mogą brać tylko osoby poniżej 60. roku życia, a starsi, którzy zagłosują, zostaną pobawieni rent i emerytur. Straszono także, że udział w plebiscycie będzie oznaczał wykluczenie z Kościoła ${ }^{97}$.

Po podliczeniu głosów okazało się, że frekwencja w plebiscycie była bardzo wysoka i wynosiła w województwie opolskim ponad 99\% (tab. 1). Wynik ten nie odbiegał od uzyskanych $\mathrm{w}$ innych regionach kraju. W województwie opolskim kart nie złożyły przede wszystkim osoby, które przebywały poza jego obszarem, np. na urlopach lub delegacjach. Odmówiło udziału w plebiscycie 0,13\% uprawnionych ${ }^{98}$.

91 APO, KW PZPR w Opolu, sygn. 248, Protokół nr 20/51 z posiedzenia Egzekutywy KW PZPR w Opolu z 18 V 1951 r., k. 74-79.

92 Ibidem, Protokół z posiedzenia Egzekutywy KW PZPR w Opolu z 11 V 1951 r., k. 44; AIPN Wr, sygn. 07/45, k. 33, Szef PUBP w Strzelcach Opolskich do Szefa WUBP w Opolu z 4 VI 1951 r., s. 5.

93 APO, KM PZPR w Opolu, sygn. 50/IV/4, Ocena sytuacji politycznej na terenie miasta Opola w m-cu maju 1951 r., k. 430.

94 APO, KP PZPR w Raciborzu, sygn. 53/II/1, Protokół z posiedzenia plenum KP PZPR w Raciborzu Z 14 V 1951 r., nlb.

95 Np. AIPN Wr, sygn. 07/67, k. 26, PUBP w Głubczycach do Szefa WUBP w Opolu z 6 VI 1951 r., s. 2; ibidem, sygn. 07/328, t. 1, k. 288, Szef PUBP w Koźlu do Szefa WUBP w Opolu z 5 VI 1951 r., s. 3; ibidem, sygn. 07/469, t. 1, PUBP w Oleśnie do Szefa WUBP w Opolu z 4 VI 1951 r.; ibidem, 07/370, k. 149, Raport okresowy Kier. Referatu V-go za okres od dnia 30 IV do dnia 31 V 1951 r.; ibidem, sygn. 07/45, k. 30, Szef PUBP w Strzelcach Opolskich do Szefa WUBP w Opolu z 4 VI 1951 r., s. 2.

96 AIPN Wr, sygn. 07/67, k. 26, PUBP w Głubczycach do Szefa WUBP w Opolu z 6 VI 1951 r., s. 2.

97 AAN, KC PZPR w Warszawie, sygn. 237/VII-1830, Informacja o działalności wroga z 17 V 1951 r., k. 201; APO, KW PZPR w Opolu, sygn. 2497, Sprawozdanie z przebiegu zebrania agitatorów gminy Popielów pow. Opole dotyczące Narodowego Plebiscytu Pokoju z 7 V 1951 r., k. 4; APO, KP PZPR w Raciborzu, sygn 53/II/1, Protokół z posiedzenia plenum KP PZPR w Raciborzu z 14 V 1951 r., nlb.; ibidem, sygn. 53/II/1, Sprawozdanie przebiegu plebiscytu narodowego na terenie Raciborza, nlb.; (Ba), Gmina Pokój walczy o pokój „Trybuna Robotnicza”, z 20 V 1951 r.

98 APO, KW PZPR w Opolu, sygn. 1733, Ocena kampanii Narodowego Plebiscytu Pokoju przez Egzekutywę KW PZPR Opole [25 V 1951 r.], nlb. 
Tabela 1. Wyniki Narodowego Plebiscytu Pokoju dla poszczególnych powiatów województwa opolskiego.

\begin{tabular}{|c|c|c|c|c|c|}
\hline Powiat & $\begin{array}{c}\text { Liczba } \\
\text { uprawnionych }\end{array}$ & $\begin{array}{l}\text { Liczba oddanych } \\
\text { głosów }\end{array}$ & $\%$ & Ile odmówito & $\begin{array}{l}\text { Ile byto } \\
\text { nieobecnych }\end{array}$ \\
\hline Kom. Miejski Opole & 38899 & 38162 & 98 & 23 & 714 \\
\hline Kom. Pow. Brzeg & 28049 & 27788 & 99 & 25 & 236 \\
\hline Kom. Pow. Głubczyce & 35062 & 34994 & 99,8 & 12 & 56 \\
\hline Kom. Pow. Grodków & 19032 & 19026 & 99,9 & 6 & $x$ \\
\hline Kom. Pow. Kluczbork & 30506 & 30481 & 99,9 & 25 & $x$ \\
\hline Kom. Pow. Koźle & 55501 & 55336 & 99,7 & 10 & 155 \\
\hline Kom. Pow. Namysłów & 17115 & 17104 & 99,9 & 11 & $x$ \\
\hline Kom. Pow. Niemodlin & 20160 & 19739 & 98 & 65 & 351 \\
\hline Kom. Pow. Nysa & 49342 & 49134 & 99,6 & 20 & 188 \\
\hline Kom. Pow. Olesno & 32914 & 32776 & 99,6 & 138 & $x$ \\
\hline Kom. Pow. Opole & 80730 & 80315 & 99,5 & 314 & 101 \\
\hline Kom. Pow. Prudnik & 53735 & 53642 & 99,8 & 48 & 45 \\
\hline Kom. Pow. Racibórz & 57104 & 57073 & 99,9 & 31 & $x$ \\
\hline Kom. Pow. Strzelce & 58756 & 58727 & 99,9 & 23 & 6 \\
\hline Razem & 576905 & 574297 & 99,5 & 751 & 1857 \\
\hline
\end{tabular}

Źródło: APO, KW PZZPR w Opolu, sygn. 1733, Pismo KW PZPR w Opolu z 23 V 1951 r., k. 117.

Najwięcej odmów odnotowano w powiecie opolskim, następnie oleskim i niemodlińskim. Częściej plebiscyt ignorowały osoby, które miały głosować w miejscu swego zamieszkania (75\%), aniżeli ci, którzy mieli składać karty w zakładach pracy. $\mathrm{Z}$ udziału w akcji rezygnowali też przede wszystkim mieszkańcy wsi (83\%), nieco ponad połowę wszystkich, którzy odmówili złożenia kart, stanowili rolnicy. Według oficjalnych wyników w głosowaniu wzięli udział wszyscy księża. Szczegółowe dane w tym zakresie prezentuje tabela 2 . 
Tabela 2. Wyniki Narodowego Plebiscytu Pokoju w województwie opolskim wg danych z 25 maja $1951 \mathrm{r}$.

\begin{tabular}{|c|c|c|c|}
\hline & Uprawnieni do głosowania & Karty podpisane & Odmówili podpisu \\
\hline Mężczyźni & 267147 & 265446 & 338 \\
\hline Kobiety & 309833 & 308926 & 413 \\
\hline W miastach & 189905 & 188765 & 126 \\
\hline Na wsi & 387075 & 385607 & 625 \\
\hline W zakładach produkcyjnych & 145538 & 144851 & 112 \\
\hline W instytucjach i urzędach & 22392 & 22780 & 38 \\
\hline W szkołach i uczelniach & 54423 & 54385 & 41 \\
\hline W miejscu zamieszkania & 354207 & 226708 & 560 \\
\hline Chłopi & 227207 & 226708 & 417 \\
\hline Księża & 492 & 492 & $x$ \\
\hline Ogółem & 576980 & 574372 & 751 \\
\hline
\end{tabular}

Źródło: APO, KW PZZPR w Opolu, sygn. 1733, Pismo KW PZPR w Opolu z 25 V 1951 r., k. 118.

Spośród 751 osób, które odmówiły złożenia kart, sporą część stanowili Świadkowie Jehowy, którzy swój dystans do akcji tłumaczyli nakazami religii - w ich ocenie pokój na świecie zależny był przede wszystkim od Boga. Niektórzy z nich, działając pod presją agitatorów, podpisywali karty, na których np. dopisywali, że opowiadają się za „pokojem Bożym”99. Świadkowie Jehowy byli przez władze partyjne uznawani za grupy dywersyjne współpracujące z Zachodem. Jeden z członków opolskiego KM PZPR, którego żona należała do tego związku wyznaniowego, dowodził, że była wśród nich prowadzana specjalna agitacja przeciwko plebiscytowi i kontaktowała się z nimi „agentura imperializmu amerykańskiego” ${ }^{100}$.

99 AAN, KC PZPR w Warszawie, sygn. 237/VII-234, Sprawozdanie z wyjazdu służbowego do woj. opolskiego z 28 V 1951 r., k. 41; ibidem, sygn. 237/VII-1696, Wewnętrzny Biuletyn Informacyjny Referatu Sprawozdawczego KW PZPR w Opolu z 14 V 1951 r.; APO, KW PZPR w Opolu, sygn. 1733, Zestawienie osób, które odmówiły podpisu pod apelem pokoju z 17 V 1951 r. (do godz. 22.00), k. 81; ibidem, sygn. 248, Protokół z posiedzenia Egzekutywy KW PZPR w Opolu z 18 V 1951 r., k. 74-79; APO, KP PZPR w Grodkowie, sygn. 43/VI/6, Sprawozdanie opisowe Powiatowego Komitetu z organizacji i przebiegu Narodowego Plebiscytu Pokoju na terenie powiatu grodkowskiego [1951 r.], nlb.; APO, KM PZPR w Opolu, sygn. 50/IV/3, Protokół z posiedzenia Egzekutywy KM PZPR w Opolu z 28 V 1951 r., k. 148. Jeśli wśród Świadków Jehowy odmawiajacych udziału w plebiscycie byli członkowie partii, wykluczano ich z szeregów PZPR. APO, KP PZPR w Oleśnie, sygn. 49/IV/5, Protokół z posiedzenia egzekutywy KP PZPR w Oleśnie z 22 V 1951 r., nlb. 
Równie liczne odmowy udziału w plebiscycie pochodziły od osób rodzimego pochodzenia. Te przypadki były szczególnie szeroko omawiane na zebraniach partyjnych. W rozmowach z agitatorami niektórzy autochtoni wyrażali swój dystans do akcji, tłumacząc, że plebiscyt jest skierowany do Polaków, a oni są Ślązakami i nie są nim objęci ${ }^{101}$. Charakterystyczna jest tu wypowiedź mieszkanki Opola, która oddając niepodpisaną kartę, oświadczyła komisji: „Bolszewizmu popierać nie będę, a poza tym granice zachodnie są jeszcze nieustalone, a ja nie jestem Polką"102. Udziału w plebiscycie odmawiały osoby deklarujące się jako Niemcy, posiadające w Niemczech najbliższą rodzinę, a przede wszystkim ci, którzy wnioskowali o wyjazd do któregoś z państw niemieckich na stałe. Najbardziej stanowczy przykład odmowy udziału w plebiscycie wyrazili mieszkańcy Golczowic, miejscowości położonej nad Odrą w powiecie niemodlińskim. Od początku kampanii bojkotowali ją - na zebranie $\mathrm{z}$ agitatorami nie stawił się oprócz sołtysa i członków KOP-u żaden z nich. W ocenie mieszkańców Golczowic plebiscyt zorganizowano po to, by narzucić Niemcom granicę na Odrze i Nysie Łużyckiej, odmawiali podpisania kart w obawie, że „zrobią ich potem Polakami”. W drugi dzień plebiscytu przewodniczący Gminnej Rady Narodowej w Skorogoszczy zakazał sprzedawania w sklepie GS towarów tym z mieszkańców Golczowic, którzy nie złożyli jeszcze kart. Komitet Powiatowy PZPR interweniował w tej sprawie, wysłał do wioski dodatkowa grupe agitatorów, którzy ostatecznie skłonili część mieszkańców do udziału w plebiscycie ${ }^{103}$. Silny opór autochtonów wobec plebiscytu odnotowano także w gminach Popielów, Dąbrówka Górna, Pokój i Zagwiździe oraz w kilku gromadach w powiecie oleskim ${ }^{104}$. $\mathrm{Z}$ powodu takich postaw przygotowano dla tych osób kartki plebiscytowe w języku niemieckim, oczekując, że te zostaną przez nich podpisane ${ }^{105}$.

W niektórych miejscowościach grupy mieszkańców, odmawiając udziału w plebiscycie, zwracały uwagę na kłopoty, z którymi się borykali. W Tułowicach gremialnie zapowiedziano niezłożenie kart w reakcji na ekscesy i nadużycia, których dopuszczał się tamtejszy funkcjonariusz MO. W tym przypadku, podobnie jak w Golczowicach, konieczna była reakcja władz partyjnych i dodatkowa praca agitacyjna ${ }^{106}$. Odmowy złożenia kart plebiscytowych były też wyrazem dezaprobaty dla ucisku fiskalnego

101 APO, KW PZPR w Opolu, sygn. 1733, Ocena kampanii Narodowego Plebiscytu Pokoju przez Egzekutywę KW PZPR Opole [25 V 1951 r.], k. 124; APO, KP PZPR Niemodlin, sygn. 47/I/1, Sprawozdanie z działalności KP PZPR w Niemodlinie za okres 15 XII 1951 - 3 I 1953 r., s. 11; ibidem, Uchwała III konferencji powiatowej PZPR w Niemodlinie z 2 XII 1951 r., s. 1; ibidem, Protokół z IV konferencji powiatowej PZPR w Niemodlinie z 17-18 I 1953 r., s. 6; AAN, KC PZPR w Warszawie, sygn. 237/VII-1678, Meldunek sytuacyjny w związku z Plebiscytem Pokoju na terenie województwa opolskiego z 17 V 1951 r., k. 41.

102 AAN, KC PZPR w Warszawie, sygn. 237/VII-1678, Meldunek Referatu sprawozdawczego KW PZPR w Opolu do KC PZPR w Warszawie z 18 V 1951 r., k. 42.

103 Ibidem, sygn. 237/VII-234, Sprawozdanie z wyjazdu służbowego do woj. opolskiego z 28 V 1951 r., k. 40.

104 Ibidem, k. 39

105 AAN, KC PZPR w Warszawie, sygn. 237/VII-1696, Wewnętrzny Biuletyn Informacyjny Referatu Sprawozdawczego KW PZPR w Opolu z 22 V 1951 r.

106 Ibidem, sygn. 237/VII-234, Sprawozdanie z wyjazdu służbowego do woj. opolskiego z 28 V 1951 r., k. 40. 
i wysokich norm dostaw obowiązkowych. I tak np. „za rygorystyczne zbieranie zboża po gromadzie" złożenia kart odmówiło 33 mieszkańców Starego Olesna ${ }^{107}$. Poszczególne jednostki odmawiały z powodów własnych, osobistych pretensji do władz czy frustracji, np. z powodu utraty pracy, przekonań religijnych („Nie mogę służyć dwóm panom, służę tylko jednemu Bogu”), trudnych warunków materialnych („Dajcie mi chleba nie papieru”). Ze sprawozdań z akcji wynika, że margines osób, które nie wzięły udziału w plebiscycie, to głuchoniemi, niewidomi lub upośledzeni psychicznie ${ }^{108}$.

W odpowiedzi na przejawy negatywnego stosunku do plebiscytu nasilano akcję agitacyjną. Do tych, którzy odmawiali złożenia kart, przybywali przedstawiciele KOP-ów i ponawiali swe wizyty dopóty, dopóki nie przekonali opornych do głosowania. Według raportów z akcji wielu z tych, wobec których użyto wyważonych argumentów i wyjaśniono im wagę plebiscytu i akcji pokojowej, „ze łzami w oczach” składało swe podpisy. W przypadkach gdy odmowy były argumentowane odczuwaną dyskryminacją czy niesprawiedliwym traktowaniem ze strony władz (odnotowywano je głównie w powiecie opolskim), agitatorzy starali się te kłopoty rozwiązywać. Kwestię tę niech zilustruje przykład z Krogulna, gdzie jedna z mieszkanek wyrzuciła agitatora z domu, utyskując, że państwo pozostawiło ją bez opieki, nie jest objęta opieką lekarską i odmówiono jej wypłacania renty. Agitator sprowadził do niej lekarza, załatwił miejsce w szpitalu i lekarstwa, a także zwrócił się do Gminnej Rady Narodowej, by zapewnić jej środki do życia. Po tej interwencji kobieta kartę podpisała ${ }^{109}$.

Według oficjalnych sprawozdań podczas plebiscytu nie stosowano przymusu. $\mathrm{Z}$ raportów partyjnych wynika, że dochodziło do pojedynczych nadużyć w tej kwestii. Informowano np. o tym, że przewodniczący Gminnej Rady Narodowej w Bogacicy wywierał nacisk na agitatorów, by wzięli udział w kampanii ${ }^{110}$. Donoszono także o komendancie milicji w gminie Sternalice, który mimo zarządzenia, że MO nie powinno brać udziału w agitacji i pracach plebiscytowych, jeździł samochodem po gromadach i kontrolował przebieg wyborów ${ }^{111}$.

107 APO, KP PZPR w Oleśnie, sygn. 49/IV/5, Protokół z posiedzenia egzekutywy KP PZPR w Oleśnie z 22 V 1951 r., nlb.

108 APO, KP PZPR w Oleśnie, sygn. 49/IV/5, Sprawozdanie z przebiegu akcji plebiscytowej na terenie powiatu oleskiego, nlb.; ibidem, Protokół z posiedzenia egzekutywy KP PZPR w Oleśnie z 22 V 1951 r., nlb.; AAN, KC PZPR w Warszawie, sygn. 237/VII-1678, Meldunek sytuacyjny w związku z Plebiscytem Pokoju na terenie województwa opolskiego z 17 V 1951 r., k. 41; APO, KW PZPR w Opolu, sygn. 1733, Zestawienie osób, które odmówiły podpisu pod apelem pokoju z 17 V 1951 r. (do godz. 22.00), k. 81; APO, KM PZPR w Opolu, sygn. 50/IV/3, Sprawozdanie z akcji przygotowawczej i przebiegu Ogólnopolskiego Plebiscytu Pokoju w Opolu [1951 r.], k. 73-77.

109 APO, KW PZPR w Opolu, sygn. 1816, Sprawozdanie z kontroli powiatu opolskiego po linii Narodowego Plebiscytu jak również szkolenia partyjnego od dnia 12-19 V 1951 r., k. 51-52; AAN, KC PZPR w Warszawie, sygn. 237/VII-234, Sprawozdanie z wyjazdu służbowego do woj. opolskiego z 28 V 1951 r., k. 39-40.

110 APO, KP PZPR w Oleśnie, sygn. 49/II/1, Protokół z posiedzenia rozszerzonego plenum KP PZPR w Oleśnie z 4 VI 1951 r., nlb.

111 APO, KW PZPR w Opolu, sygn. 248, Protokół nr 20/51 z posiedzenia Egzekutywy KW PZPR w Opolu z 18 V 1951 r., k. 74-79. 


\section{Podsumowanie}

Władze przystępowały do Narodowego Plebiscytu Pokoju z wachlarzem zadań i celów. Prowadzona kampania miała wyczulić społeczeństwo na zagrożenie wojenne, wskazać metody, jakimi należy zabiegać o zachowanie pokoju. Poprzez tak utrzymany tok narracji starano się kształtować poczucie patriotyzmu i wyczulać na kwestię obrony państwowej suwerenności. Podkreślano przy tej okazji nienaruszalność granic i - co było dość istotne w kontekście specyfiki województwa opolskiego - prawa Polski do Ziem Zachodnich. W myśl oficjalnych przekazów plebiscyt miał przyczyniać się do rozwijania międzynarodowej solidarności i braterstwa. Kampania miała zobrazować wzrost sił pokojowych zarówno Wschodu, jak i Zachodu oraz wskazać na słabości konkurencyjnego obozu „imperialistów”. Z akcją tą łączono również nadzieje na związanie społeczeństwa z partią komunistyczną, zyskanie akceptacji obywateli dla proponowanych przez rządzących rozwiązań politycznych, ustrojowych, gospodarczych, np. planu sześcioletniego, zakładania spółdzielni produkcyjnych itp. ${ }^{112}$

Z całą pewnością Narodowy Plebiscyt Pokoju okazał się propagandowym sukcesem władz. W podsumowaniach kampanii oceniano, że wypadła lepiej i spotkała się z bardziej otwartym przyjęciem niż wcześniejsze tego typu akcje, np. pomocowa dla Korei czy zbierania podpisów pod Apelem sztokholmskim ${ }^{113}$. Uzyskano bardzo wysoką frekwencję - udział w plebiscycie wzięło 99,5\% uprawnionych mieszkańców województwa opolskiego. Większość głosów, czego nie zakładano wcześniej, zebrano już w dwóch pierwszych dniach i planowana na niedzielę 20 maja wzmożona akcja propagandowa na wsiach nie była już tak bardzo potrzebna. Wobec tego, że udziału w plebiscycie odmówiły jednostki, ogłoszono, że uzyskano społeczną jednomyślność. W ocenach kampanii jako osiągnięcie wskazywano także rozbudowanie terenowych struktur WKOP - założono wiele nowych komitetów, głównie w małych miejscowościach, zakładach pracy i na wsiach. Jako kolejny sukces podano to, że dotarto z agitacją do każdego obywatela. Z uznaniem wyrażano się także o skali podjętych działań propagandowych i bogactwie jej form oraz środków. W sprawozdaniach z kampanii przekonywano, że spowodowała ona uspokojenie nastrojów w społeczeństwie i pokazała, jak skutecznie zabiegać o zachowanie pokoju ${ }^{114}$.

Władze akcję plebiscytową wykorzystały do zaprezentowania swego ideowego przesłania - treści polityczne zręcznie wkomponowywano w kampanię na rzecz ochrony pokoju. Działania te były obliczone na pozyskanie nowych sympatyków,

112 APO, KW PZPR w Opolu, sygn. 988, Protokół z odprawy sekretarzy i kierowników Wydziałów Propagandy KP[PZPR] w KW [PZPR] w Opolu z 14 IV 1951 r., k. 32; ibidem, sygn. 248, Protokół z posiedzenia Egzekutywy KW PZPR w Opolu z 11 V 1951 r., k. 44.

113 Zwracał na to uwage np. Władysław Szal, który wskazywał, że w powiecie raciborskim w plebiscycie nie wzięło udziału tylko kilkanaście osób, a pod Apelem sztokholmskim nie podpisało się 300 osób. APO, KP PZPR w Raciborzu, sygn. 53/II/1, Protokół z posiedzenia plenum KP PZPR w Raciborzu z 22 V 1951 r., nlb. Zob. też: APO, KW PZPR w Opolu, sygn. 1733, Ocena kampanii Narodowego Plebiscytu Pokoju przez Egzekutywę KW PZPR Opole [25 V 1951 r.], k. 129.

114 APO, KW PZPR w Opolu, sygn. 1733, Ocena kampanii Narodowego Plebiscytu Pokoju przez Egzekutywę KW PZPR Opole [25 V 1951 r.], k. 125. 
wzmożenie zaciągu do PZPR, ZMP lub innych organizacji. Wiele obiecywano sobie po tych wymienianych $\mathrm{w}$ raportach 45 tys. zaangażowanych $\mathrm{w}$ kampanię agitatorach. Wprost przyznawano, że działający w niej ludzie to „poważna armia do stałej pracy politycznej"115. Pozyskane nowe zaplecze miało ułatwić poszerzenie pracy propagandowej w regionie i utrzymanie uzyskanej w trakcie kampanii aktywności na tych ternach województwa, gdzie wcześniej mieszkańcy zachowywali wyraźny dystans do kwestii politycznych ${ }^{116}$. Żywe dyskusje nad Apelem Światowej Rady Pokoju miały poprawić świadomość opolan w kwestii zagrożenia wojennego, a także potrzeb obronności kraju. Przy tej okazji bardzo klarownie wskazywano wroga, którym miał być szeroko rozumiany Zachód, utożsamiany głównie z USA, a jako sojusznika w zmaganiach pokojowych lansowano ZSRR. W ten sposób starano się kreować akceptację współpracy politycznej Polski i jej wschodniego sąsiada. Zadanie to było dość istotne w Opolskiem, zważywszy, że jego mieszkańcy, zwłaszcza autochtoni, żywili wyraźną awersję do Związku Radzieckiego. Oszczercza kampania wobec USA miała także na celu wywoływanie niechęci do kierunku zmian, jaki Amerykanie nadali państwu zachodnioniemieckiemu, co na Śląsku było bardzo istotne, zważywszy na żywe tam sentymenty proniemieckie.

W podsumowaniu kampanii plebiscytowej podkreślano, że stała się ona okazją do poznania potrzeb i bolączek społeczeństwa. Wnoszone podczas spotkań przed plebiscytem skargi obnażyły skalę nadużyć i nieprawidłowości, m.in. w terenowych komitetach partii i urzędach. Jak zapewniano w sprawozdaniach, zapobiegliwość agitatorów i aktywistów pomogła rozwiązać część ze zgłaszanych problemów. Opolski KW PZPR wyciągnął z tych sytuacji wnioski i na zebraniu podsumowującym akcję zalecił, by w przyszłości komitety powiatowe partii intensywniej monitorowały sytuację na podległym im terenie i reagowały na przypadki nadużyć i nieprawidłowości. Analizując nastroje w regionie, przyznano ponadto, że w związku z obiekcjami, które wobec plebiscytu zgłaszały osoby ubiegające się o wyjazd do Niemiec, należy im umożliwić opuszczenie Polski, by uniknąć rozwoju napięć. Akcję potraktowano także jako kolejne doświadczenie w mobilizowaniu mas i wypracowywaniu metod zwalczania wrogich wystąpień. Jak zaznaczano, udało się w trakcie trwania kampanii zdemaskować przeciwników, odsłonić metody ich działania i „bardzo szeroką skalę perfidii i różnorodność metod kłamstwa"117. Zaznaczano także, że podejmowana kampania przeciwko plebiscytowi nie znalazła szerszego oddźwięku.

Podejmowane w trakcie kampanii przed Narodowym Plebiscytem Pokoju działania nie do końca spełniły pokładane w nich oczekiwania. Wbrew głoszonym powszechnie hasłom nie udało się osiągnąć wcześniej zamierzonych celów. Akcja plebiscytowa nie przyczyniła się do integracji społeczeństwa. W jej trakcie utrzymywał

115 Ibidem, k. 126; APO, KM PZPR w Opolu, sygn. 50/IV/3, Protokół z posiedzenia Egzekutywy KM PZPR w Opolu z 28 V 1951 r., k. 148

116 APO, KM PZPR w Opolu, sygn.50/IV/4, Ocena sytuacji politycznej na terenie miasta Opola w m-cu maju 1951 r., k. 430.

117 APO, KW PZPR w Opolu, sygn. 1733, Ocena kampanii Narodowego Plebiscytu Pokoju przez Egzekutywę KW PZPR Opole [25 V 1951 r.], k. 129. 
się podział między ludnością rodzimą a napływową. Wyraźnie rysowały się różnice między grupami społecznymi - wskazywano głównie dystans, jaki utrzymywał się między zaangażowanymi $\mathrm{w}$ akcję przedstawicielami inteligencji a robotnikami i chłopami, wykazującymi wobec nich „pewne onieśmielenie”. W komitetach pokojowych nie osiągnięto planowanej ponadpartyjnej współpracy. Wiele z KOP-ów zostało zdominowanych przez członków PZPR, którzy odsuwali od zadań osoby spoza partii, w zamkniętym gronie ustalali zakres i harmonogram prac, uważając pozostałych „za niezbędną dekorację"118. Nie wszystkie komitety pracowały jednakowo intensywnie, w niektórych powiatach, np. oleskim, bardziej skupiono się na działaniach na wsi, zaniedbując akcje w miastach. Prowadzone z członkami komitetów pokojowych i agitatorami szkolenia wielokrotnie pozostawały na niskim poziomie. W trakcie seminariów ograniczano się do odczytywania instrukcji. Przełożyło się to na marne dyskusje w trakcie zbiórek i masówek, a agitatorzy nie radzili sobie z zadawanymi im pytaniami i zgłaszanymi uwagami. Aktyw mało miejsca poświęcał ideologicznemu znaczeniu tej akcji, cechowała go pewna mechaniczność działania i skupienie na pozyskaniu jak największej liczby uczestników plebiscytu. W czasie kontroli przygotowań do głosowania okazywało się, że część z deklarowanych zebrań nie odbyła się ${ }^{119}$. Sporo kłopotu sprawiło też tempo przygotowań. Akcja nie przebiegała planowo. Ponieważ szkolenia się przedłużały, zbyt mało czasu zostało na agitację indywidualną. Niski okazał się poziom kampanii prowadzonej przez ludzi bardzo młodych. Przede wszystkim nie potrafili odpowiadać na zadawane im pytania. Dodatkowo część z nich wykazywała się szczególnym brakiem taktu, gdy np. wyśmiewali starszych mieszkańców szukających analogii między Narodowym Plebiscytem Pokoju a tym, który pamiętali z 1921 r. Młodzi kpili także z religijności mieszkańców, zalecając im np. wieszanie w miejsce krzyży czy wizerunków świętych portretów Stalina i Bieruta lub gołąbków pokoju. Przy takich incydentach konieczne okazywały się ingerencje aktywu partyjnego i łagodzenie tych sytuacji przez wysyłanie w te miejsca starszych aktywistów ${ }^{120}$. Okazało się także, że część agitatorów została wytypowana błędnie. Wielu z nich nie podjęło swych obowiązków. W niektórych miejscowościach kilkukrotnie trzeba było zmieniać ich skład,

118 Ibidem; AAN, KC PZPR w Warszawie, sygn. 237/VII-234, Notatka z wyjazdu służbowego do woj. opolskiego z 4 V 1951 r., k. 17; AAN, KC PZPR w Warszawie, sygn. 237/VII-234, Sprawozdanie z wyjazdu służbowego do woj. opolskiego z 28 V 1951 r., k. 36.

119 AAN, KC PZPR w Warszawie, sygn. 237/VII-234, Sprawozdanie z wyjazdu służbowego do woj. opolskiego z 28 V 1951 r., k. 41; APO, KW PZPR w Opolu, sygn. 248, Protokół nr 20/51 z posiedzenia Egzekutywy KW PZPR w Opolu z 18 V 1951 r., k. 74-79; ibidem, Protokół z posiedzenia Egzekutywy KW PZPR w Opolu z 11 V 1951 r., k. 44; APO, WKOP, sygn. 1, Sprawozdanie z działalności politycznej i organizacyjnej Woj. Komitetu Obrońców Pokoju w Opolu i trenowych Komitetów Obrońców Pokoju za 1951 r., nlb.; APO, KP PZPR w Oleśnie, sygn. 49/IV/5, Informacja KP PZPR w Oleśnie o przebiegu przygotowań do Narodowego Plebiscytu Pokoju na terenie powiatu oleskiego, nlb., APO, KP PZPR w Grodkowie, sygn. 43/VI/6, Sprawozdanie opisowe Powiatowego Komitetu z organizacji i przebiegu Narodowego Plebiscytu Pokoju na terenie powiatu grodkowskiego [1951 r.], nlb., APO, KM PZPR w Opolu, sygn. 50/IV/3, Protokół z posiedzenia Egzekutywy KM PZPR w Opolu z 28 V 1951 r., k. 148; Cała Opolszczyzna dokumentuje swa wolę walki o pokój i Plan 6-letni, „Trybuna Robotnicza”, z 12 V 1951 r.

120 APO, KW PZPR w Opolu, sygn. 248, Protokół nr 20/51 z posiedzenia Egzekutywy KW PZPR w Opolu z 18 V 1951 r., k. 74-79; AAN, KC PZPR w Warszawie, sygn. 237/VII-234, Sprawozdanie z wyjazdu służbowego do woj. opolskiego z 28 V 1951 r., k. 36. 
a do części wiosek konieczne okazało się sprowadzenie agitatorów z innych gmin. Dochodziło też do sytuacji, gdy agitatorzy odmawiali swego udziału w plebiscycie, a nawet namawiali swoje otoczenie do bojkotu głosowania. Sytuacje takie odnotowano np. w powiecie kozielskim, strzeleckim i oleskim ${ }^{121}$. Wbrew lansowanym, np. na łamach prasy, opiniom zaangażowanie $\mathrm{w}$ akcję plebiscytową dalekie było od powszechnego, najczęściej włączały się $w$ nią jednostki. Zwracał na to uwagę I sekretarz KW PZPR w Opolu Roman Nowak w podsumowaniu kampanii, mówiąc, że podawane oficjalnie dane o liczbie agitatorów są zawyżone i faktycznie nie przekraczają 27 tys., bo tyle osób zostało przeszkolonych ${ }^{122}$.

Odrębnym kłopotem okazał się kolportaż kart. Nie docierały one wszędzie lub dostarczano je do gminnych komitetów w ostatniej chwili, pozostawiając agitatorom tylko jeden dzień na ich przekazanie głosującym. Część mieszkańców otrzymała kilka blankietów, np. zarówno w miejscu zamieszkania, jak i w zakładzie pracy. Agitatorzy słabo instruowali o procedurze głosowania, w związku z tym część kart trafiała do punktów niepodpisana, tylko z wypisanym na nich imieniem i nazwiskiem. Wśród innych nieprawidłowości odnotowano m.in. to, że w niektórych miejscach karty zamiast agitatorów roznosiły dzieci. Dochodziło także do sytuacji, gdy agitatorzy sami zbierali podpisane karty i odnosili je do wyznaczonych punktów, co głosujący mieli uczynić osobiście ${ }^{123}$. Inną trudnością był brak środków na oprawę plebiscytu, dlatego m.in. dekoracje wykonywano często własnym sumptem. Część komitetów pokojowych podchodziła do kwestii propagandy wizualnej dość luźno i na podległych im obszarach prezentowała kilka monotematycznych haseł. Warto zwrócić uwagę także na to, że główny temat kampanii propagandowej, czyli pakt pięciu mocarstw, był w kampanii niemal nieobecny. Szafowano hasłami o szeroko rozumianym zagrożeniu wojennym, konieczności obrony pokoju, ale o randze tej umowy, jej przyszłych sygnatariuszach czy skutkach nie wypowiadano się właściwie wcale.

Kampania plebiscytowa wraz z jej hasłami antywojennymi stała się wytrychem, który miał otworzyć społeczeństwo na głos władzy, furtką, przez którą partia miała zyskać społeczne zaufanie. Rządzący starali się stworzyć wspólny front z obywatelami, ustawić się z nimi w jednym szeregu. $\mathrm{O}$ ile trudno byłoby to uzyskać, występując $\mathrm{z}$ apelem o jawne poparcie dla np. zmian ustrojowych czy planu sześcioletniego,

121 APO, KW PZPR w Opolu, sygn. 248, Protokół nr 21/51 z posiedzenia Egzekutywy KW PZPR w Opolu z 25 V 1951 r., k. 89; APO, KM PZPR w Opolu, sygn. 50/IV/3, Protokół z poszerzonego posiedzenia Egzekutywy KM PZPR w Opolu z 22 V 1951 r., k. 239-245; APO, KP PZPR w Oleśnie, sygn. 49/IV/5, Sprawozdanie z przebiegu akcji plebiscytowej na terenie powiatu oleskiego, nlb.; AAN, KC PZPR w Warszawie, sygn. 237/VII-1678, Meldunek Referatu sprawozdawczego KW PZPR w Opolu do KC PZPR w Warszawie z 18 V 1951 r., k. 42; 39 tys. aktywistów..

122 APO, KW PZPR w Opolu, sygn. 248, Protokół nr 20/51 z posiedzenia Egzekutywy KW PZPR w Opolu z 18 V 1951 r., k. 74-79.

123 Ibidem; APO, KP PZPR w Oleśnie, sygn. 49/IV/5, Protokół z posiedzenia egzekutywy KP PZPR w Oleśnie z 22 V 1951 r., nlb.; ibidem, Sprawozdanie z przebiegu akcji plebiscytowej na terenie powiatu oleskiego, nlb.; APO, KM PZPR w Opolu, sygn. 50/IV/3, Protokół z posiedzenia Egzekutywy KM PZPR w Opolu z 15 V 1951 r., k. 172-175; AAN, KC PZPR w Warszawie, sygn. 237/VII-234, Sprawozdanie z wyjazdu służbowego do woj. opolskiego z 28 V 1951 r., k. 41. 
o tyle kampania antywojenna była tym polem, na którym pomiędzy władzą a społeczeństwem łatwiej było osiągnąć współpracę. No bo przecież kto chciałby wojny? Osób, które otwarcie przyznawały, że liczą na konflikt zbrojny, było niewiele. W związku z tym wynik plebiscytu został zaprezentowany nie tylko jako masowy protest przeciwko zagrożeniu światowego pokoju. Ogłoszono go jako dowód jednomyślnego poparcia dla władz, wyraz akceptacji prowadzonej przez nią polityki, zmian ustrojowych i gospodarczych. Głosy oddane w plebiscycie miały dowodzić, że mieszkańcy województwa, występując przeciw wojnie, nie godzą się na ewentualne zmiany granic, lecz akceptują zaprowadzoną na Śląsku Opolskim przed sześciu laty zwierzchność polską. Szczególnej mocy w tym kontekście nabierały upowszechniane opinie reprezentantów ludności rodzimej, którzy wypowiadali się z uznaniem o Polsce Ludowej. Warto zwrócić uwagę również na fakt, że wykorzystywane w kampanii argumenty o odradzaniu się w Niemczech Zachodnich Wehrmachtu i ruchów nazistowskich dotykały przeszłości tej części mieszkańców województwa, która w systemie hitlerowskim do 1945 r. funkcjonowała. Zastanawiać może, jak rodzimi mieszkańcy, dawni obywatele III Rzeszy, którzy mieli w obu państwach niemieckich swoich krewnych i znajomych, odbierali w trakcie kampanii ataki na RFN - państwo to prezentowano przed plebiscytem jako ośrodek odradzającego się z inspiracji zachodnich kapitalistów rewizjonizmu i kraj ucisku społecznego. Niestety wykorzystane w niniejszym opracowaniu materiały nie pokazują autentycznych reakcji społecznych na agitację podczas plebiscytu pokoju, nie charakteryzują w pełni nastrojów i motywów, którymi się kierowano, składając podpisy pod Apelem berlińskim. Trudno ocenić skalę wystąpień dowodzących braku przychylności dla plebiscytu i jednoznacznie stwierdzić, czy były one incydentalne. Przede wszystkim brakuje relacji osób pamiętających te wydarzenia. Skąpe materiały dokumentujące prace aparatu bezpieczeństwa w tym okresie nie wskazują, by było inaczej. Niewykluczone jednak, że bardziej szczegółowa kwerenda w zasobach Instytutu Pamięci Narodowej pozwoliłaby te wątpliwości rozwiać.

Cały ogromny wysiłek organizacyjny podczas Narodowego Plebiscytu Pokoju nie okazał się owocny, ponieważ wnioskowany pakt pokoju nie został podpisany. Wprawdzie wojna, którą straszono, nie wybuchła, jednak apele społeczne nie były argumentem przeważającym w tej kwestii. Uzyskane poczucie jednomyślności władzy i różnych grup społecznych okazało się krótkotrwałe, a wykreowany na czas głosowania entuzjazm i aktywność zarówno komitetów pokojowych, jak i agitatorów szybko wygasły ${ }^{124}$. W niczym to jednak nie wyhamowało tempa ówczesnej akcyjności. Tuż po ogłoszeniu wyników plebiscytu społeczeństwo zostało objęte nową kampanią propagandową powszechnej subskrypcji Narodowej Pożyczki Rozwoju Sił Polski. 


\section{Bibliografia}

Bałłaban J., Młodzieżowe Warty Pokoju w Zakładach Przemysłu Dziewiarskiego w Głuchołazach, „Dziennik Zachodni”, z 17 V 1951 r.

Kamiński J., Zadanie, które zostanie wykonane na piq̨tkę, „Trybuna Robotnicza”, z 20 V 1951 r.

Kaniak W., Ksiqdz - patriota, „Trybuna Robotnicza”, z 21 V 1951 r.

Leksykon pokoju, red. J. Kukułka [et al.], Warszawa 1987.

Osmańczyk E., Cztery przyczyny, „Dziennik Zachodni”, z 14 V 1951 r.

Ostrowski S., Manifestacyjny przebieg Plebiscytu w powiecie kozielskim, „Trybuna Robotnicza”, z 22 V $1951 \mathrm{r}$

Pocałun Z., Wielki dzień Paczkowa, „Trybuna Robotnicza”, z 22 V 1951 r.

Ślusarczyk J., Ruch obrońców pokoju w latach 1948-1989. Kompendium, Warszawa 1996. 


\section{Organizacja i przebieg Narodowego Plebiscytu Pokoju w województwie opolskim}

Streszczenie: Między 17 a 22 maja 1951 r. w Polsce, pod auspicjami Polskiego Komitetu Obrońców Pokoju trwał Narodowy Plebiscyt Pokoju. Akcja ta miała na celu zgromadzenie podpisów pod Apelem berlińskim ogłoszonym przez Światową Radę Pokoju w sprawie podpisania Paktu Pokoju między pięcioma mocarstwami światowymi. Głosowanie poprzedzała intensywna kampania propagandowa w obronie pokoju i piętnująca „podżegaczy wojennych”. W województwie opolskim, podobnie jak w całym kraju, powstały przed plebiscytem liczne komitety pokojowe, zwerbowano grupę ok. 40 tys. agitatorów, urządzono wiele spotkań, masówek, manifestacji. Agitację prowadzono za pośrednictwem prasy, filmu, radia i radiowęzłów. Dla uczczenia plebiscytu podejmowano zobowiązania produkcyjne i przygotowano specjalne dekoracje. W województwie opolskim 99,5\% upoważnionych złożyło karty z podpisami pod Apelem Światowej Rady Pokoju. Nieliczne odmowy pochodziły głównie od świadków Jehowy oraz rodzimych mieszkańców, którzy deklarowali się jako Niemcy lub zabiegali o wyjazd na stałe do Niemiec. Celem akcji było wskazanie źródeł zagrożenia wojną i metod zachowania pokoju. Ponadto kampania miała spowodować wzrost społecznej akceptacji dla władz i realizowanego przez nią programu zmian politycznych i gospodarczych. Uzyskane efekty tych starań okazały się krótkotrwałe.

Słowa kluczowe: ruch obrońców pokoju, Narodowy Plebiscyt Pokoju, województwo opolskie, Górny Śląsk, apel pokojowy, Komitet Obrońców Pokoju, Apel berliński, stalinizm, Światowa Rada Pokoju, propaganda 